\title{
Workplace Bullying and Employee Outcomes: A Moderated Mediated Model
}

\begin{abstract}
This paper investigates the relationship between workplace bullying and employee outcomes in a healthcare setting. Drawing on HR process theory, we investigate the mediating role of the perceived effectiveness of implementation of anti-bullying practices on employee outcomes and whether targeted line manager training was a moderator of that relationship. Our multi-level analysis (utilising responses from 1,507 employees within forty-seven hospitals with matched HR Director interviews), finds that the relationship between workplace bullying and employee outcomes is partially mediated by employees’ perceived effective implementation of intended antibully practices. The mediated relationship is moderated by targeted line manager training in anti-bullying practices. The mediated moderation model illustrates that it is effective implementation of anti-bullying practices enhanced by targeted training that is required to reduce bullying probabilities and their associated negative employee outcomes. The paper contributes to resource based view (RBV) of the firm, HR process and human capital theories. The implications for future research and practice are discussed.
\end{abstract}

Keywords: HR process theory, workplace bullying, anti-bullying practices, employee outcomes, line manager training, multi-level analysis. 


\section{Introduction}

Workplace bullying represents an important and increasingly researched negative employee behaviour in organisations (Djurkovic, McCormick \& Casimir, 2008; Nielsen et al., 2009; Nielsen, Mageroy, Gjerstad \& Einarsen, 2014). It is defined as behaviour that 'takes place when one or more persons systematically and over time, feel that they have been subjected to negative treatment on the part of one or more persons, in a situation in which the person(s) exposed to the treatment have difficulty in defending themselves against them. It is not bullying when two equally strong opponents are in conflict with each other' (Einarsen \& Skogstad, 1996; pp. 190191). Workplace bullying is prevalent across a variety of organisational settings (Zapf, Escartin, Einarsen, Hoel \& Vartia., 2011) and the global economic and financial crises may have further contributed to the incidence of workplace bullying (D’Cruz, Noronha \& Beale, 2014). Employers can incur significant costs related to workplace bullying (Samnani \& Singh, 2014). For example, it is estimated that workplace bullying may cost UK organisations $£ 13.75$ billion annually (Giga, Hoel \& Lewis., 2008). Exposure to bullying in the workplace is not only associated with reduced health and well-being among those being bullied (e.g., Hogh, Hoel \& Carneiro, 2011), it is also associated with individual, unit and organisational outcomes related to performance and productivity (Mathisen, Einarsen, \& Mykletun, 2008), negative outcomes for patient care (Laschinger, 2014), increased absenteeism (Asfaw, Chang \& Ray, 2014), increased turnover intentions (Houshmand, O’Reilly, Robinson \& Wolff, 2012) and reduced job satisfaction and engagement (Rodríguez-Muñoz, Baillien, De Witte, MorenoJiménez \& Pastor, 2009).

It therefore makes sense, given the significant costs associated with workplace bullying and the array of negative employee outcomes, for organisations to both prevent bullying from occurring in the first instance and, where it occurs, to reduce its negative outcomes. Employers 
can use a number of strategies including work design (Notelaers, Baillien, De Witte, Einarsen \& Vermunt, 2012), workplace climate interventions (Skogstad, Torsheim, Einarsen \& Hauge, 2011) and the implementation of anti-bullying HR practices (Woodrow \& Guest, 2014). Despite the wealth of research on the prevalence of workplace bullying, its determinants and prevention, little research has been undertaken on understanding the role of the impact of effectively implemented anti-bullying HR practices on the workplace bullying-outcomes relationship. In addition, there are few insights into the impact of training - anti-bullying human capital - targeted at line managers to help them effectively implement these practices. There are two important gaps that this paper addresses.

We develop and test a model informed by HR process theory and, in particular, the significance of differences between intended and implemented anti-bullying HR practices that employees experience and the mechanisms that influence the gaps between both of these approaches (Ostroff \& Bowen, 2016). The intended-implemented gap is an area of considerable debate and research within HRM (Guest \& Conway, 2011; Ehrnrooth \& Bjorkman, 2012; Khilji \& Wang, 2006); however, there is a surprising gap in empirical studies that have investigated this issue in the context of different HR practice domains. We suggest that the area of anti-workplace HR practices is an interesting area in which to study this gap. Many organisations have a large number of intended practices aimed at preventing workplace bullying, yet workplace bullying is pervasive (Woodrow \& Guest, 2016). Therefore, an important first contribution to this paper is to investigate the intended-implemented gap in the context of an under-researched HR practice domain - anti-bullying workplace practices - and whether it acts as a mediator of the workplace bullying-outcomes relationship. We argue that the role of the line manager in helping to bridge the intended-implemented gap is likewise not effectively understood in the context of anti-workplace bullying practices. Line managers are the first line of defence when issues of workplace bullying arise. They perform a number of 
important implementation roles. First, they have direct responsibility for implementing antibullying policies and practices (Hutchinson \& Purcell, 2010). They communicate these policies, they help clarify expectations and behaviour-outcome contingencies for employees and they can contribute to the creation of an anti-bullying climate (Zohar \& Luria, 2010). Yet, consistent with findings in other areas, line manages may be less willing and competent to implement anti-bullying workplace policies and practices (Woodrow \& Guest, 2014). Line manages may also be hesitant to get involved in resolving bullying issues and frequently adopt informal approaches (Woodrow \& Guest, 2016). They frequently lack the skills required to handle complex workplace bullying issues and may pass them over to the human resource function to resolve (Hutchinson \& Purcell, 2010). Training on anti-bullying policies and practices is considered an appropriate strategy to enhance their competence. Training practices may help to bridge the intended-implemented gap (Woodrow \& Guest, 2016). Therefore, the second contribution of this paper is to investigate whether targeted anti-bullying training for line managers will impact employee perceptions of the effectiveness of implementation of antibullying practices. We therefore shed light on an important boundary condition that constrains the mediated relationship. Finally, we study these phenomena in a healthcare context. This context is particularly potent when it comes to investigating workplace bullying and its outcomes. Healthcare organisations have amongst the highest rates of workplace bullying, with nurses particularly at risk (Houshmand et al., 2012; Laschinger, 2014; McVicar, 2003). These organisations have implemented a variety of HR practices to address workplace bullying issues; however, relatively little is known about how effectively they are implemented.

In summary, we utilise multi-respondent data and multi-level modelling to investigate both a mediating and moderating hypothesis to better understand the relationship between workplace bullying and employee outcomes. The research addresses a significant gap because to the best of our knowledge, there is only very limited research that investigates the intended- 
implemented gap in the context of anti-bullying HR practices and the specific contribution of targeted line manager training aimed at helping them implement these practices effectively (see Woodrow \& Guest, 2014 and Woodrow \& Guest, 2016 for notable exceptions).

\section{Literature Review and Hypotheses}

The Mediating Influence of Effectively Implemented Anti-Bullying HR Practices

The investigation of workplace bullying and its outcomes has attracted significant scholarly attention (Jackson, Clare \& Mannix, 2002; Lee \& Brotheridge, 2006; Quine, 1999). Much of this research operates from an emotion-centred model and argues that workplace bullying can influence many employee outcomes (Spector \& Fox, 2002). Therefore, workplace bullying is conceptualised as a form of social stressor that can result in negative behavioural consequences for employees (Hauge, Skogstad \& Einarsen, 2010). Of particular relevance to this study researchers have investigated the relationship between bullying and job satisfaction (Woodward \& Guest, 2014), intention to leave (Houshmand, et al., 2012) and errors and near misses affecting patient care (Laschinger, 2014).

While there is a significant literature outlining recommended HR policies and practices for the management of bullying (content), less attention has been paid to their effective implementation (process). Where intended practices are implemented effectively employees are more likely to share a common interpretation of what is important and what behaviours are expected and rewarded. Effective implementation will help to foster the emergence of organisational climate (collective perceptions) from psychological climates (individual-level perceptions), and the variability among employee perceptions of the meaning of a situation should be minor, reflecting a common desired content (Bowen \& Ostroff, 2004, p 213; Russo, Mascia \& Morandi, 2016). This research has emphasised the importance of the role of 
employee perceptions in translating intended HR practices into employee behaviours and outcomes and, in turn, organisational outcomes.

Drawing on HR process theory (Bowen \& Ostroff, 2004) it can be argued that the presence (content) of bullying/anti-bullying policies and procedures is a necessary condition, but evidence shows that it is unlikely to be a sufficient condition for preventing, or at least reducing workplace bullying. The importance of differentiating between intended (HR content) and effectively implemented (HR processes) practices have been recognised in the HRperformance literature for over a decade, yet studies are limited (Guest \& Conway, 2011; Khilji \& Wang, 2006; Wright \& Nishii, 2006). Guest and Conway (2011) found that the association between performance outcome measures was generally stronger when HR practices were effectively implemented compared to the presence of more practices. Extending this study, Woodrow and Guest (2014) examine how anti-bullying policies are implemented in the context of an NHS hospital with 'best practice' policies but which still experienced high rates of workplace bullying. Indeed, this analysis shows that perceived effective implementation was very uneven, which resulted in persistently high levels of bullying.

Researchers have more recently investigated more indirect relationships and highlighted the importance of mediators. We propose that the effectiveness of implemented anti-bullying policies will mediate the relationship between workplace bullying and employee outcomes. Therefore, we propose that the effectiveness of the implementation of anti-bullying policies by organisations will perform a 'protection and preservation' function by reducing or eliminating the possibility of workplace bullying behaviours (Sparrow \& Makram, 2015). The question therefore arises as to why effectively implemented anti-bullying HR practices act as an important mediator of the workplace bullying employee outcomes relationships. We argue that where anti-bullying HR practices are perceived to be effectively implemented by employees, 
the impact of bullying will be lessened (Bentley et al., 2012). Where employees experience bullying, but have the opportunity to avail of organisational HR practices designed to prevent or reduce the incidence of bullying, outcomes such as job dissatisfaction, intention to leave and near misses, may be decreased or lessened. Therefore, effectively implemented anti-bullying HR practices can buffer the relationship between workplace bullying and negative employee outcomes. Effectively implemented anti-bullying HR practices may be a type of reciprocity within social exchange theory (Coyle-Sharpiro \& Conway, 2004). Therefore, it follows that where employees perceive that anti-bullying HR practices are effectively implemented, they will conclude that the organisation is doing something to address bullying and employees will contribute through greater efforts to offset or diminish the negative impacts of bullying.

Hypothesis 1: The perceived effectiveness of implemented anti-bullying HR practices (process) rather than the presence of more practices (content) will mediate the relationship between workplace bullying and employee outcomes.

The Moderating Role of Targeted Line Manager Training

The present study also investigates whether targeted line manager training moderates the proposed indirect relationship between workplace bullying and employee outcomes, suggesting that the relationship will be weaker where there is more targeted training. The line manager is central to employee perceptions of effective implementation of HR practices. Purcell, Kinnie, Hutchinson, Rayton \& Swart, 2003 have found that line managers can trigger positive behaviours by the way they implement HR practices and policies which influence employees' discretionary behaviours. In the context of workplace bullying, line managers are likely to be central for preventing negative behaviours and acts among their employees. Line managers will therefore influence how employees perceive the intended-effectively implemented gap in the context of HR practices (Khilji \& Wang, 2006; Woodrow \& Guest, 
2016). It makes sense for organisations to target training to enhance the skills and competencies of line managers to implement anti-bullying HR practices. Training is an important set of practices that can enhance the resources of line manager (Bell, Campbell \& Cycyota, 2002) to implement HR practices effectively. Targeted and regular training of line managers should therefore contribute to a reduction in workplace bullying incidents (Hutchinson \& Purcell, 2010).

Specifically, targeted training will enhance line manager's ability, motivation and opportunity to effectively implement anti-bullying HR practices (Boselie, Dietz \& Boon, 2005). It will enhance their knowledge, skills and confidence in the implementation of antibullying practices. In addition, it will enhance their motivation to perform tasks associated with anti-bullying HR practices and it increases their opportunity to contribute effectively to organisational implementation processes. These training practices should therefore help to narrow the gap between intended anti-bullying HR practices and the effectiveness of practices. Indeed, Hutchinson and Purcell's (2010) study in UK hospitals found that inadequate training to develop HRM skills was significant and was a frequent constraint that negatively impacted the ability to implement HR effectively. Woodrow and Guest (2014) found that perceived effective implementation by senior and local management could minimise levels of bullying which, in turn, contributed to better employee outcomes.

We propose that where organisations provide greater amounts of targeted training on anti-bullying HR practices to line managers, employees will perceive that they can more effectively avail of these practices, which further diminishes the negative impacts of workplace bullying. Therefore, it is plausible to argue that the greater the amount of targeted training of line managers the more likely it is that the indirect effects of workplace bullying on employee outcomes will be weakened. The indirect association between workplace bullying and 
employee outcomes through the perceived effective implementation of anti-bullying HR practices is dependent upon levels of targeted training so that the relationship will be weaker where there is more targeted training.

Hypothesis 2: The indirect association between workplace bullying and employee outcomes through perceived effectiveness of implementation of anti-bullying HR practices is conditional upon levels of line manager training, so that the relationship between workplace bullying and employee outcomes is weaker when line manager training is high.

\section{Methodology}

\section{Sample and Procedure}

The hypotheses were tested by collecting data from nurses and midwives and HR Directors in private and public sector hospitals in Ireland. Nurses and mid-wives data was collected through an on-line survey and HR Director data through semi-structured telephone interviews. The survey was sponsored by the Irish Nurses and Midwifery Organisation (IMNO) which is the largest nursing and midwifery trade union in Ireland (31,564 members). The survey was open for one month (July 2014) on the INMO's website and hard copies were also made available when requested. ${ }^{\mathrm{i}}$ A total of 2,442 usable surveys were obtained (a 7.7\% response rate). Given that the focus of this analysis is how employees experience and evaluate HR practices and their perceptions of workplace bullying, respondents who had line manager responsibilities are excluded from this analysis $(n=513)$, reducing the sample to 1,929 employees. Respondents are therefore referred to hereafter as 'employees'.

A comparison of the surveys by age, geographical dispersion and public and private sector organisations to the INMO's membership profile found no biases amongst the 
respondents. Nine percent of respondents were not INMO members and had accessed the survey through the union's website.

The survey questionnaire was strictly anonymous. However, in order to conduct followup interviews with HR Directors that could be matched to employee responses, respondents were given the option of identifying their employer ('work unit'). It was emphasised that this question was strictly to assist with research and how an employer had been identified would never be revealed. Ninety-one percent of employee respondents $(1,755)$ provided details of their work unit. Guidelines on conducting multi-level analysis were followed (Shen, 2015). Specifically, to have sufficient power (e.g., 0.90) to detect cross-level interactions, a sample of 30 units containing 30 individuals each is recommended (Hofmann et al., 2000). Fifty separate units met the individual criteria of having 30 or more employees who had completed the online survey. In the second stage of the research, the HR Director at each of these 50 units was contacted through a personalised letter followed by an email and was asked to participate in a study of HR systems and workplace bullying within the health care sector in Ireland. Fortyseven telephone interviews, lasting on average fifty minutes, were successfully completed representing a response rate of 94 per cent. As there are approximately 66 hospitals in Ireland (48 public (72.7\%) and 18 private (27.3\%)), the sample represents 71 per cent of hospitals. Thirty-six (76.6\%) were from the public sector and $11(23.4 \%)$ from the private sector. The final sample of employees within these forty-seven hospitals is 1,507.

\section{Study Variables}

Intended Practices (Employees and HR Director)

Woodrow and Guest's (2014) comprehensive list of 'Recommended Inclusions for a Best Practice Approach to the Management of Workplace Bullying’ was utilised to evaluate content and implementation (see Appendix A). ${ }^{\text {ii }}$ HR Directors were asked to identify the presence of 
practices from all sections. The maximum possible number of 'best practices' that HR Directors could identify was 44 and for employees 38 (employees were not asked about the 6 measures related to 'systematic data monitoring). Cronbach's $\alpha=0.745$ for employees and $\alpha$ $=0.821$ for HR Directors. The mean number of practices reported by employees was 18.7 (standard deviation of 9.9) and 32.7 by HR Directors (standard deviation of 4.67). Consistency checks were carried out to compare the HR Directors' and employee responses to intended practices. The correlation between HR Directors' and employees' responses in terms of intended practices across workplace units ranged from a low of 0.41 to a high of $0.67(p<0.01$ $-p<0.001)$. These correlations suggest moderate to strong consistence in the HR Director's and employees’ knowledge of intended practices.

The appropriateness of these 'best practices' in the context of Irish hospitals was piloted with 12 hospital HR managers (none were HR Directors, as these were target respondents for the semi-structured interviews) and 25 nurses/midwives. The practices were found to apply, though with high levels of variance, across respondents’ workplaces. ${ }^{\text {iii }}$

Perceived Effective Implementation: Proposed Mediator (Employees)

Building on the work of Tsui (1987), Huselid, Jackson \& Schuler (1997) and Guest and Conway (2011), employees were asked about the perceived effectiveness of each 'best practice' policy. Employees were asked to indicate 'the level of effectiveness' (of each 'best practice') for the prevention of workplace bullying. All responses were provided on a five-point Likert scale ranging from “' not at all effective' (1) to 'highly effective' (5); in addition, the option of ‘not applicable’ in my organisation” was given. Cronbach’s $\alpha=0.801$.

Targeted Training and Development Practices for Line Managers: Proposed Moderator (HR Director) 
We adapted Aragon \& Sanz Valle’s (2013) holistic measure of management training. Specifically, we differentiate between training incidence and training intensity. The training questions were answered by HR Directors only.

Training incidence (within the past year) was measured as follows: (a) mediation and/or conflict management training ( 0 = no; 1 = yes) (see Leon-Pérez, Arenas and Butts, 2012); (b) coaching and mentoring to improve line manager's competencies to 1 . Preventing bullying (0 $=$ no; $1=$ yes); 2 . Quickly identifying bullying $(0=$ no; $1=$ yes $)$; and 3 . implementing the organisation's recommended anti-bullying practices and policies if/when bullying occurs $(0=$ no; 1 = yes); and (if response b was not applicable) 3. Formal training on how to implement the organisation's anti-bullying practices and policies ( $0=$ no; $1=$ yes) (see Cooper-Thomas, et al., 2013; and Mikkelsen, Hogh and Puggaard, 2011). The index ranged between 0 and 4.

Training time was measured using the mean of hours of specific anti-bully training received by line managers (adapted from Holzer, Block, Cheatham, \& Knott, 1993; and Krueger \& Rouse, 1998).

The resources dedicated to anti-bullying training for line managers using an ordinaltype qualitative variable with five-point Likert scales, capturing the variation in the resources invested by the organisation in this training in the previous two years $(1=$ 'significant decline' - 5 = 'significant rise’).

As these measures were adapted from general questions about management training, they were subsequently adapted based on an extensive review of the literatures pertaining to conflict resolution, conflict management and methods used to prevent bullying and conflicts at work. This review was conducted by two of the three study authors who are both experts in the field of human resource development (HRD). Detailed feedback on the draft questions were obtained from six practitioners who specialise in sexual harassment training (2 
individuals), workplace bullying training (2 individuals) and mediation and conflict resolution training (2 individuals). A focus group was then held with all eight of these individuals to further refine the questions. The new instruments were then piloted with the 12 hospital HR managers. At this stage only very minor adjustments to some of the wording of the questions were needed as it was agreed that the instruments accurately reflected the incidences and intensity of the types of anti-bullying related training provided to line managers in Irish hospitals.

Workplace Bullying: Dependent Variable (H1) and Explanatory Variable (H2) (Employees)

Einarsen, Hoel, Zapf and Cooper's (2003) widely used definition of workplace bullying was used in the employee survey. The definition given was: "Bullying at work means harassing, offending, socially excluding someone or negatively affecting someone’s work tasks. In order for the label bullying to be applied to a particular activity, interaction or process it has to occur repeatedly and regularly (e.g. weekly) and over a period of time (e.g. about six months)”. Respondents were asked whether, based on this definition, they had been bullied in the past six months. Just over 53 percent of respondents indicated that they experienced workplace bullying in the past 6 months.

In addition to these direct questions about perceived bullying, the Negative Acts Questionnaire (NAQ) developed by Einarsen, Raknes, and Mattiesen (1994), which is a validated instrument for measuring the frequency, intensity and prevalence of workplace bullying, was also used. We used The Negative Acts Questionnaire - Revised (NAQ-R; Einarsen,, Hoel, and Notelaers, 2009) that measures the prevalence of 22 potentially bullying behaviours that can occur. Example items include: being ignored or excluded, persistent criticism of your work and effort, and being shouted at or being the target of spontaneous anger. The scale includes three main factors: personal bullying, work-related bullying and physically 
intimidating bullying. Respondents were asked to rate the frequency that they have experienced each of the negative acts in the last six months using a 5-point scale (never, now and then, monthly, weekly, daily).

NAQ-R provides prevalence data for each of the 22 negative behaviours as well as an overall score. The overall NAQ-R score could range from 22 (meaning that the respondent 'never' experienced any of the 22 negative behaviours) to a maximum of 110 (meaning that the respondent experienced all of the 22 negative behaviours on a daily basis).

As the NAQ-R tool avoids the term 'bullying' or 'harassment', respondees in our survey were also asked about their perceived experiences of bullying and very specific criteria were used to merge the responses between the NAQ-R and perceptions of bullying questions. Only where employees reported experiencing at least 25 percent of the possible negative acts and indicated that they had been bullied is the respondent categorised as 'bullied'. This is a binary variable coded as 1 if the respondent met the two criteria and 0 otherwise. The use of this cut-off reduces the number of respondents who experienced workplace bullying in the past 6 months to 51.1 percent, which shows a high level of consistency between the two measures. The use of both a definition of bullying and the NAQ-R helps to address widely acknowledged difficulties in measuring bullying in workplaces (Samnani \& Singh, 2012).

\section{Dependent Variables}

Employee Outcomes (Employees) 
Job satisfaction was measured using the Brayfield and Rothe's (1951) measure of overall job satisfaction comprising six items ranging from $1=$ 'strongly agree' to 5 = 'strongly disagree’. Example items include: I find real enjoyment in my job, I would not consider taking another kind of job, and I feel fairly well satisfied with my job. The reliability and validity of this scale has been demonstrated in previous studies (e.g., Brooke, Russell, \& Price, 1988). Cronbach's $\alpha=0.802$.

We used Chatman’s (1991) four item measure to capture turnover intentions ranging from 1 = 'strongly agree' to 5 = 'strongly disagree’ (see Houshmand et al., 2012 for a recent application in the context of work place bullying). Example items include: you prefer another more ideal job than the one you now work in, you intend to leave this organisation within the next 12 months, and if you have your own way, will you be working in this organisation three years from now. Cronbach's $\alpha=0.813$.

The third measure examined is the frequency of 'errors and near-miss events'. The health care literature widely recognises that the reporting and prevention of such events is critical for patient safety (e.g., Crane, Sloane, Elder, Cohen, Laughtenschlaeger, Walsh \& Zimmerman, 2015). Aspden, Corrigan, Wolcott and Erickson’s (2004) definition was used: "an event/situation in which a negative outcome could have occurred but did not, either by chance or because the problem was identified and corrected” (Aspden et al, 2004; cited in Crane et al., 2015, p. 453). Respondents were asked to indicate whether in the past six months they were responsible for any near misses and errors ranging from $1=$ never/not at all to $5=$ frequently (e.g., once a week). Cronbach's $\alpha=0.732$.

Control Variables (Employees and HR Director)

We controlled for four individual-level variables commonly used in the workplace bullying literature (e.g., Houshmand et al., 2012): gender ( 1 = male, 2 = female); tenure $(1=0$-2 years, 
$2=3-5$ years, $3=6-10$ years and $4=$ more than 11 years $)$; employment status $(1=$ permanent and 2 = other (including temporary and agency)); and trade union members $(1=$ yes, $2=$ no). These data were drawn from the survey of employees.

The organisational level data were obtained from telephone semi-structured interviews with HR Directors. We controlled for organisational size (log of size) and sector (private $=0$,

public $=1$ ). Given that HR practices - high performance work practices (HPWPs) - are found in many studies to be significantly associated with employee outcomes (see Guest, 2011 for a review), we drew upon Datta, Guthrie, and Wright's (2005) study and controlled for 18 practices. In this study, the HR practices are measured by an index which was created by averaging all items. Cronbach's $\alpha=0.78$ which is comparable to Datta, Guthrie and Wright (2005) $\alpha=0.78$; and Fu et al., 2015; $\alpha=0.71$. The mean number of practices used was 12.9.

\section{Analytical Strategy}

To model the relationships proposed in the hypotheses, we make use of multilevel models, which take into account the hierarchical nature of our data (Snijders \& Bosker, 1999). Given that the dependent variable in hypothesis 1 is dichotomous (workplace bullying), it is estimated using multilevel binomial logistical regression (MLRA) in which we have 1,507 observations at the individual lower level (level-1) and 47 at the higher unit (organisational) level (level-2). Hypothesis 2 is estimated by a two-level hierarchical linear modelling (HLM) analysis according to the enter method (see Van Woerkom \& Meyers, 2015, p. 90; Hofmann \& Gavin, 1998).

To establish mediation, we used HLM in conjunction with recommended steps to test mediation by Kenny, Kashy, and Bolger (1998) and Chen and Bliese (2002). It is further recommended that mediation analyses be based on formal significance tests of the indirect effect, of which the Sobel (1982) is best known. However, the Sobel test rests on the 
assumption that the indirect effect $a b$ is normally distributed (Edwards \& Lambert, 2007). This assumption is tenuous, because the distribution of $a b$ is known to be non-normal, even when the variables constituting the product $a b$ are normally distributed. Therefore, bootstrapping is recommended. Through the application of bootstrapped confidence intervals (CIs), it is possible to avoid power problems introduced by asymmetric and other non-normal sampling distributions of an indirect effect (Pituch, Whittaker, \& Stapleton, 2005).

We were able to estimate the CIs of the indirect effects using the Monte Carlo method provided by Selig and Preacher (2008). To assess moderated mediation (Hypothesis 2), we examined four conditions recommended by Muller, Judd, \& Yzerbyt, 2005; Ng, Ang, \& Chan, 2008 (see Appendix B for details).

\section{Results}

\section{Quality Checks on Data}

First, we assessed the presence and influence of common method variance (CMV). As the HR Directors were the single-respondent for the data on HPWPs, targeted training incidence, targeted training hours per manager, and resources on targeted training analysed, the potential for CMV exists for these variables. Firstly, the Harman's single-factor test illustrated a onefactor solution which accounted for only 24.3 percent of the variance. Secondly, using a latent variable approach we conducted a confirmatory factor analysis where items loaded on their respective latent construct as well as a latent CMV factor (Podsakoff, MacKenzie, Lee \& Podsakoff, 2003). This was then compared to a model without the latent CMV factor. In the latent CMV factor model, all unstandardized parameter estimates are significant and a comparison of the standardized estimates between models illustrated that none showed a difference above 0.2 . These analyses do not preclude the possibility of common method 
variance; however, they indicate that common method variance is not a major concern and is unlikely to confound the interpretation of the results.

Second, we investigated multicollinearity. The correlation matrix (Table 1) indicates that the data do not suffer from multicollinearity since none of the correlations exceed 0.53 . Kline (2005) suggests that indications of substantial multicollinearity arise with correlations above 0.85. In addition, the variance inflation factors (VIF) in each regression equation were low-ranging from 1.17 to 2.03 - well below the lower end of the recommended threshold in the literature of 4 - 5 (Rogerson, 2001).

Third, as we were interested in investigating perceptions of workplace bullying and perceived effective implementation - based on a direct consensus model - we established within-group agreement and between-group variability to decide whether individual level scores could be aggregated to the unit (here, hospital) level. In line with previous research (Ehrhart \& Naumann, 2004), we estimated Rwg scales for each unit, and ICC (1) and ICC (2) values. Rwg scores provide an indication of the level of agreement within each unit and the ideal cut-off is more than .70 (Kozlowski \& Klein, 2000). The average Rwg scores in our sample was 0.75 (range 0.71 - 1.00) for workplace bullying; 0.83 (range 0.73-1.00) for perceived effective implementation; 0.85 for job satisfaction $(0.74-1.00)$; 0.83 for intended turnover $(0.72-1.00)$; and $0.76(0.73-1.99)$ for near misses/mistakes in patient care.

Next, we ran null or unconditional models (see Tables $2-5$ ) with no predictor variables in order to examine whether there were significantly systematic between-hospital variances in the five dependent variables (bullying probability, perceived effective implementation, job satisfaction, intended turnover and near misses/mistakes). The results provided support for significant variations in workplace bullying $\left(\mu_{0}, \tau_{0}=87.15, \chi^{2}(46)=416.64, p<0.001\right.$, ICC1 $=$ 0.58, ICC2 $=0.87)$; perceived effective implementation $\left(\mu_{0}, \tau_{0}=98.33, \chi^{2}(46)=812.66\right.$, 
$p<0.001, \mathrm{ICC} 1=0.32, \mathrm{ICC} 2=0.83)$; job satisfaction $\left(\mu_{0}, \tau_{0}=87.15, \chi^{2}(46)=416.64, p<0.001\right.$, ICC1 $=0.36, \operatorname{ICC} 2=0.87)$; intended turnover $\left(\mu_{0}, \tau_{0}=90.09, \chi^{2}(46)=438.29, p<0.001\right.$, ICC1 $=0.44$, ICC2 $=0.89)$; and mistakes and near misses $\left(\mu_{0}, \tau_{0}=98.29 .09, \chi^{2}(46)=633.49\right.$, $p<0.001$, ICC $1=0.51$, ICC2 $=0.87)$.

These results indicate that 58\%, 32\%, 36\%, 44\% and 51\% of bullying probability, perceived effective implementation, job satisfaction, intended turnover and mistakes and near misses, respectively, resided in hospitals all of which exceed the 0.20 ICC1 threshold. The ICC2 estimates also all exceed the recommended 0.80 threshold. These results provided sufficient statistical justification for the aggregation of individual measures to the group level (Bliese, 2000). This analysis, in addition to the nested structure of our variables, provides valid support to used HLM to analyse our data (Snijders \& Bosker, 1999).

\section{Hypothesis Testing}

Hypothesis 1 proposed that the relationship between workplace bullying and employee outcomes would be mediated by perceived effective implementation of anti-bullying policies rather than the content, or presence of more practice. Several steps were required to test this hypothesis. First, it was necessary to examine the relationship between the presence and effective implementation of policies and practices and the probability of experiencing workplace bullying. The results presented in Table 2 report results for the dichotomous variable ( 1 if bullied; 0 if not bullied) by mixed effects multi-level logistic regression (using 'megrlogit' in Stata 13). At the individual level (Model 2), trade union membership has a significant negative association with the probability of being bullied $(p<0.01)$; and at the organisational level (Model 3), working in a larger organisation is associated with a greater probability of being bullied $(p<0.05)$; and working in the private sector is negatively associated with being 
bullied $(p<0.05)$. A higher number of HPWPs practices are not significantly associated with the probability of being bullied.

To test for mediation, we followed Baron and Kenny’s (1986) procedures to assess the mediation of perceived effective implementation: 1 . Workplace bullying is significantly negatively associated with job satisfaction $(B=-0.35$; $p<0.001)$ (see Model 4 in Table 3); and positively and significantly associated with higher turnover intention $(B=0.45 ; p<0.001)$ (see Model 4 in Table 4); and more near misses/mistakes in patient care $(B=0.29 ; p<0.001)$ (see Model 4 in Table 5); 2. The results in Table 2 (Model 5) demonstrate that there is a significant association between perceived effective implementation and workplace bullying $(B=-2.27$; $p<0.01$ ); and when regressing the dependent variable (employee outcomes) on boththe independent variable and the mediator, 3. the mediator (perceived effective implementation) significantly predicts the dependent variables $(B=0.35 ; p<0.001$ for job satisfaction; $\mathrm{B}=$ 0.22; $p<0.01$ for intended turnover; and $B=-0.16$; $p<0.01$ for near misses and mistakes (Model 6, Tables 3-5); however, condition 4 that the independent variable (workplace bullying) no longer predicts the dependent variable (employee outcomes) is not accepted ( $B=-0.17 ; p<0.05$ for job satisfaction; $B=0.23 ; p<0.01$ for intended turnover; and $B=0.18 ; p<0.05$ for near misses and mistakes) (Model 6, Table 3-5). Therefore, perceived effective implementation of practices only partially mediates the relationship between workplace bullying and employee outcomes, and hypothesis 1 is not fully supported. ${ }^{\text {iv }}$

We then test hypothesis 2 which proposes that the mediated relationship between workplace bullying and employee outcomes through perceived effective implementation would be moderated by the three types of targeted line manager training (incidence, time, and resources). First, we found that each of the targeted training was significantly associated with the three employee outcomes. Targeted training incidence is positively associated with 
increased job satisfaction $(B=0.29 ; p<0.001)$; lower intended turnover $(B=-0.16 ; p<0.01)$; and fewer mistakes $(B=-0.32 ; p<0.001)$; targeted training hours per line managers is positively associated with increased job satisfaction $(B=0.18$; $p<0.05)$; lower intended turnover $(B=$ 0.09; $p<0.05)$; and fewer mistakes $(B=-0.22 ; p<0.05)$; and targeted resources are positively associated with increased job satisfaction $(B=0.23$; $p<0.01)$; lower intended turnover $(B=$ 0.12; $p<0.05)$; and fewer mistakes $(B=-0.28 ; p<0.01)$ (Models 7-9 respectively, Table 3-5).

We then centred the predictor (perceived effective implementation) and moderator variables (targeted training) prior to creating the product terms for testing interaction effects and used the standardised score in subsequent analysis and estimated these relationships by a cross-level moderator analysis in HLM (e.g., Raudenbush, Bryk, Cheong, Congdon, \& Du Toit, 2004). The results show that targeted training moderates the influence of perceived effective implementation on all employee outcome measures.

Specifically, the interactions for targeted training incidence and perceived effective implementation are positive for job satisfaction $(B=0.18$; $p<0.01)$; negative for intended turnover $(B=-0.18 ; p<0.05)$; and negative for mistakes $(B=-0.24 ; p<0.01)$; the interaction term for targeted training hours per line managers is positive for job satisfaction $(B=0.11$; $p<0.05)$; negative for intended turnover $(B=-0.13$; $p<0.05)$; and negative for mistakes $(B=-$ 0.16 ; $p<0.05$ ); and finally, the interaction term for targeted resources is positive for job satisfaction $(B=0.14 ; p<0.05)$; negative for intended turnover $(B=-0.10 ; p<0.05)$; and negative for mistakes $(B=-0.21 ; p<0.01$ ) (Models 10-12 respectively, Table 3-5).

To further explore this interaction, we used simple slopes computation and graphed the interactions using high (1SD above the mean) and low (1SD below the mean) levels of the three moderator variables - targeted training incidence, hours and resources. The results of the 9 plots of the interactions are reported in Figures 1-9 (see Appendix C) and represent 95 percent 
CIs. Using the technique developed by Aiken and West (1991), we calculated the significance of each of these simple slopes for each employee outcome measure. The general pattern to emerge is that the positive association between job satisfaction and perceived effective implementation is significantly stronger where there are high levels of each of the targeted training methods ( $p<0.001$ incidence (TT-I); $p<0.05$ hours (TT-H); and $p<0.01$ resources (TTR)); and insignificant where there are low levels of targeted training. Similar patterns of significance were found in relation to the negative relationships between intended turnover and near mistakes/incidences, perceived effective implementation and high levels of targeted training (low levels are not significant in any of the estimations). Therefore, Hypothesis 2 was supported, and Condition 2 for assessing moderated mediation was also met (see Appendix B for details).

To further assess moderated mediation, we examined Condition 4, which requires the magnitude of the conditional indirect effect of workplace bullying via perceived effective implementation to be different across high and low levels of the three types of targeted training. Following Preacher et al. (2007), we operationalized high and low levels of each targeted training method one standard deviation above and below the mean of each of the training methods and further examined the significance of indirect effects of workplace bullying on employee outcomes via perceived effective implantation for units with high and low levels of targeted training using bootstrapped 95 percent CIs (Selig \& Preacher, 2008).

We used PROCESS software (Hayes, 2013) to simultaneously test the moderated mediation model relationships proposed in Hypothesis 2. PROCESS uses a path analysis approach described by Preacher et al., (2007) and Edwards and Lambert (2007) and allows for a bootstrap test of indirect effects in mediation (MacKinnon, Lockwood, Hoffman, West, \& Sheets, 2002) at various levels of the moderator(s). Specifically, we test the four conditions 
proposed by Muller, et al., 2005 and Ng, et al., 2008 to assess moderated mediation (Appendix B). In units with high targeted training incidence, results revealed significant conditional indirect effects of workplace bullying. The indirect effects when each of the targeted training methods are weak includes zero, indicating that there is no significant direct effect under this condition (see Appendix D for details). The results reinforce those shown in Figures 1-9 namely that only under conditions of high levels of targeted training do we find a significant mediated effect. The mediated or indirect effect is therefore conditional on high levels of targeted anti-bullying training, which supports Hypothesis 2.

\section{Discussion}

While researchers have conducted many studies on the relationship between workplace bullying and employee outcomes, there are few studies that have investigated the role of implemented anti-bullying HR practices and HR practices targeted at line managers to enhance their competence to implement these practices. Therefore, based on HR process theory (Bowen \& Ostroff, 2004), we investigated the mediating effects of the perceived effectiveness of implementation of anti-bullying HR practices on the workplace bullying - employee outcomes relationship. We additionally investigated the moderating effect of targeted line manager training on the relationship between workplace bullying and employee outcomes through the indirect effect of employees' perceptions of effective implementation of anti-bullying HR practices. The two hypotheses of the present study were supported and we found evidence of partial mediation (H1) and moderation (H2). Most significant of all, we found that the indirect association between workplace bullying and employee outcomes through effective implementation of anti-bullying HR practices was conditionally dependent upon high levels of targeted line manager training. Hence, the findings indicate that when employees perceive that line managers are effectively trained, less bullying will take place and the negative associations 
with employee outcomes are weakened, albeit still significant. Therefore, the simultaneous test of the hypotheses using a moderated mediation analysis provides important insights into the role of line managers in bridging the intended-implementation gap.

Our study makes a number of contributions to theory. First, it highlights the importance of utilising both the content and process-based approach theoretical lenses for analysing potential relationships between HR practices and organisational outcomes. It demonstrates that the content approach may make misspecification errors in investigating how employee outcomes are influenced by intended HR practices which can also contribute to misspecifications in the examination of the relationship between HR practices and outcomes. Consistent with theoretical and significant empirical evidence, it is found that HPWPs are associated with higher job satisfaction, lower turnover intentions and lower rates of near misses and mistakes in patient care. However, these results show that an organisation could invest heavily in HPWPs but unless its anti-bullying policies are effectively implemented there will be negative employee outcomes. These negative outcomes can significantly reduce the potential impact of HPWP investment in organisations and the associated objective of better organisational performance. Likewise, a greater number of 'best practice' anti-bullying work practices (content) were not significantly associated with a lower probability of workplace bullying but their effective implementation (process) as perceived by employees was indeed significantly associated with less bullying and mitigated some of the associated adverse organisational outcome effects associated with bullying

Second, prior research - which until relatively recently - primarily focussed on a macroframework, where both HRM and performance are considered at the firm level, ignoring the role of employees’ actual perceptions of intended practices (Lepak, Liao, Chung \& Harden, 2006; Liao, Toya, Lepak \& Hong, 2009). This research highlights the necessity of multi-level analysis to capture complex HR processes in organisations. This study implemented robust 
measurements of the intended-implemented gap by deriving data from two sources at two different levels of analysis. The results show that employees' attributions and perceptions of the organisation's intention to prevent negative employee behaviours (bullying) only have their desired effect when policies are perceived to be implemented effectively. Effective implementation appears to signal to employees that bullying behaviours will not be regarded as acceptable behaviours within the organisation. The findings are significant because they lend support to the growing body of evidence that the HR-outcomes relationship is contingent on effective implementation of practices. The findings also support the view that 'strong' HR processes shape shared employee reactions (Katou, Budhwar, \& Patel, 2014; Nishii, Lepak \& Schneider, 2008).

Third, the study highlights the importance of human capital expanding capabilities for the effective implementation of intended HR practices. From the origins of the resource-based theory of the firm which provides the theoretical underpinning of most of the HRMperformance literature, scholars have emphasised the importance of human capital as a source of competitive advantage (Barney, 1991). However, how human capital influences competitive advantage is underdeveloped, leading to recent calls to drill down to the 'micro-foundations' of resources and capabilities - and specifically to examine the skills and abilities of individual employees (Coff \& Kryscynski, 2011). Emphasis has tended to be given to organisational 'stars' in the emerging literature, yet line managers' pivotal role in reducing employees' often idiosyncratic interpretations of intended HR practices, is key to strengthening the intended HR system and is thereby a critical dimension of the 'black box' the HR-performance relationship.

This study showed that the while the resourcing of line managers' anti-bullying human capital (expenditure and time) contributed to more effective implementation, it was specific types of anti-bullying human capital investments (e.g., mediation and/or conflict management 
training) that was most significantly associated with more effective implementation (the moderating effect was stronger).

The explanations for this moderated relationship are various. First, where employees perceive that line managers are effectively trained in the implementation of anti-bullying HR practices, they will trust their managers to act competently and proactively in situations where bullying arises. They will also be confident that the bullying issue will be resolved, therefore reducing the negative outcomes of bullying. Second, investment in targeted line manager training may contribute to the development of trust amongst line managers and their direct reports, thus making it more likely that bullying issues will be reported and resolved, further reducing the negative consequences of bullying. Our study findings demonstrate the importance of anti-bullying human capital investment as an important investment for organisations to make.

Overall our findings in respect of line managers are significant and underscore that for employees the effective implementation of HR practices is inextricably linked to how competently line manages perform the task of implementation. However, employees must perceive that these policies and practices simply do not remain in the HR handbook but become reality through effective implementation. HR practitioners should be conscious of this and gauge how effectively practices are implemented.

\section{Methodological Limitations of the Study}

The present study is based on data collected using questionnaires with two data sources, employees and HR directors. The data is therefore self-report and subject to mono-method bias. Research does, however, indicate that in reality this bias may be significantly lower than assumed (Spector, 2006). Many of our variables focus on intra-psychological dimensions such as perceived exposure to bullying, turnover intentions and perceptions of job satisfaction and 
as Spector (2006) argued 'it is difficult to get accurate information about internal states - such as attitudes and emotions, with anything other than self-reports” (p. 229). The data collected are quantitative in nature and thus the rich data that qualitative analysis related to the key study variables were not captured and this is recognised as a limitation but an important opportunity for future research.

The HR Director provided data on the full list of possible 'best practice' anti-bullying practices and the measures of targeted line manager training in anti-bullying policies and procedures. Such reports are subject to common methods variance bias (CMV). However, the Harman's single-factor test and latent variable statistical analysis suggest our findings are not impacted greatly by CMV. Nevertheless, the potential for CMV cannot be definitively eliminated.

Another limitation is that there are likely to be two types of line managers: those that bully and those that do not. We were not able to differentiate between the two types of line managers that employees in the sample were exposed to which is likely to influence our results. It will be critical that future research controls for past and current bullying behaviours of both line managers and employees.

Finally, we collected all of the data at the same time. Therefore, it is not possible to draw causal inferences based on our empirical findings, even though our theoretical framework supported the relationships we found. We also cannot rule out reciprocal and/or reverse causation. Specifically, we investigated how three dimensions of targeted training for line manages - incidence, time and resources - enhanced the perceptions of employees of effective implementation of anti-bullying HR practices.

\section{Practical Implications}


This study first examined the extent of 'best practice' anti-bullying practices were in place, how effectively these practices were implemented and the relationship between these measures and the probability of bullying. It is important to highlight that employees were given 38 potential practices to identify, yet the median number of practices identified by employees was only 18.7 or less than 50 per cent of possible practices. This is in contrast to HR Directors who were given the option of 44 practices, with a mean of 32.7 reported (74\% of possible practices). This indicates a need for greater organisational initiatives to publicise the presence of often extensive practices. Such initiatives would also be important for influencing perceived organisational support (POS) among employees against bullying and could include initiatives such as open and respectful communication about bullying and how it can be prevented (see Cooper-Thomas et al., 2013 for elaboration).

Second, the results of the present study underscore the importance of preventing bullying in organisations by paying attention to two important issues: a) the effective implementation (employee perceptions) of anti-bullying HR practices and b) the implementation of targeted training of line managers to develop their competence to address bullying issues. However, we find that the first without the second is insufficient. Therefore, organisations should pay attention to how effectively line managers are trained. We found, for example, that the incidence of training - rather than the resourcing or time spent on training - was the strongest moderator. Specifically, training in mediation and/or conflict management and coaching and mentoring to improve line manager's competencies to manage various potential stages of the bullying process. These stages include: 1 . prevention; 2, quickly identifying bullying; 3. implementing the organisation's recommended anti-bullying practices and policies if/when bullying occurs, and, where competencies were not developed around these potential stages, the provision of formal training in how to implement the organisation's anti-bullying practices and policies was also found to be effective. 
Investment in sophisticated anti-bullying HR practices will pay dividends provided line managers are competent to effectively implement these practices. It is critical that such training is formally evaluated by both line managers and employees and that longitudinal data are collected and monitored on whether such training reduces work place bullying overtime.

While it is common for employees to be surveyed frequently on engagement issues, this research suggests that employees should also be surveyed on their awareness of intended HR practices and critically, their perceptions of the effectiveness of implemented practices, as these responses are likely to be important input variables that contribute to engagement outcomes. It is employees' perceptions of the effectiveness of intended and implemented practices that are critical to HR processes and these inputs need to be formally evaluated by HR practitioners. In addition, it is recommended that many organisations would benefit from formally assessing the risk of bullying by using the Bullying Risk Assessment Tool (BRAT, Hoel \& Giga, 2006). The Tool consists of five factors: organisational fairness, team conflict, role conflict, workload, and leadership. Example items include: "New staff are made to feel welcome when starting employment in the organisation” and "Conflict in my work unit is common” and can be applied at the individual and group level. Hoel and Giga (2006) developed the BRAT instrument and concluded that it was a valid and reliable measure of the risk of bullying. While, the BRAT's psychometric properties are of a similar standard to NAQ-R, the advantage the BRAT could offer to organisations is that its purpose is to identify risk within the organisation whereas the NAQ-R is largely a research tool designed to measure the prevalence of bullying. This may be of particular value in sectors and small and medium enterprises (SMEs) where bullying has not been widely reported but may be at high risk of such behaviours.

Finally, this study found positive associations between the number of high performance work practices (HPWPs) and higher rates of job satisfaction, lower rates of intended turnover and near misses/mistakes. However, HPWPs were not associated with a lower probability of 
workplace bullying. In order for organisations to benefit fully from the presence of HPWPs, it is critical that these practices operate simultaneously with high levels of effectively implemented 'best practice’ anti-bullying practices. Only through this duality will the virtuous performance cycles associated with HPWS be realised.

\section{Implications for Future Research}

Our findings open up a number of questions for future studies. We conducted our study in a health care context; therefore, researchers should investigate whether the findings reported here are generalizable to other contexts. Given the high rate of bullying in the healthcare sector, researchers should investigate the relevance of the findings in a low bullying context. Further future research should investigate the relationships researched here using longitudinal designs (see Rodríguez-Muñoz et al., 2009). We investigated our study variables at the individual level of analysis, therefore researchers should investigate whether the relationships hold at higher levels of analysis (e.g. team, unit and organisation levels). Finally, future research should examine in further detail how the micro-foundations of human capital investments may influence both employee and organisational level outcomes.

\section{Conclusion}

Studies of the consequences of workplace bullying are increasingly commonplace in the literature; however, few studies have investigated mediating mechanisms and boundary conditions and whether specific organisational contingencies impact the mediated relationship. The findings of the present study show that the perceived effectiveness of implementation of anti-bullying HR practices by employees mediates the relationship between workplace bullying and employee outcomes. However, this relationship is significantly boosted where organisations provide targeted training to line managers to enhance their skills to implement anti-bullying HR practices. We make an important contribution to the literature by highlighting 
the significance of the intended-implemented gap in the context of anti-bullying HR practices - thereby contributing to both RBV and HR process theories - and we have narrowed down that relationship to the specific effect of focused line manager training. Therefore, our findings substantiate the view that HR practices of effectively implemented anti-bullying HR practices can contribute to lower levels of workplace bullying as well as minimising the negative consequences of bullying behaviour. The study was conducted in the health care sector, a sector with high levels of workplace bullying. This suggests that the effective implementation of antibullying HR practices, enhanced by targeted line manager training, should make a very significant impact. 


\section{References}

Aragón, I.B., \& Sanz Valle, R. (2012). Does training managers pay off? International Journal of Human Resource Management, 24: 1671-1684. doi: 10.1080/09585192.2012.725064.

Aspden, P., Corrigan, J.M., Wolcott, J., \& Erickson, S.M. (eds) (2004). Committee on Data Standards for Patient Safety. Patient Safety: Achieving a New Standard for Care. Washington, DC: National Academies Press.

Asfaw, A.G., Chang, C.C., \& Ray, T.K. (2014). Workplace mistreatment and sickness absenteeism from work: results from the 2010 National Health Interview syrvey, American Journal of Industrial Psychology, 57: 202-213. doi: 10.1002/ajim.22273. Epub 2013 Oct 26.

Barney, J. (1991). Firm Resources and Sustained Competitive Advantage. Journal of Management, 17: 99-120.

Baron, R.M., \& Kenny, D.A. (1986). The Moderator-Mediator Variable Distinction in Social Psychological Research: Conceptual, Strategic, and Statistical Considerations. Journal of Personality and Social Psychology, 51, 1173-1182. Journals@Ovid. Accession Number: 00005205-198612000-00010.

Bell, M.P., Campbell Quick, J., \& Cycyota, C.S. (2002). Assessment and Prevention of Sexual Harassment of Employees: An Applied Guide to Creating Healthy Organizations. International Journal of Selection and Assessment, 10: 160-167. doi: 10.1111/1468-2 389.00203.

Bentley, T.A., Catley, B., Cooper-Thomas, H., Gardner, D., O’Driscoll, M.P., Dale, A., \& Trenberth, L. (2012). Perceptions of workplace bullying in the New Zealand travel industry: Prevalence and management strategies. Tourism Management, 33: 351-360. http://dx.doi.org/10.1016/j.tourman.2011.04.004.

Bliese, P.D. (2000). Multilevel Modelling in R: A Brief, the Multilevel Package, and the NLME Package. Washington, D.-C. USA: Walter Reed Army Institute of Research.

Boselie, P., Dietz, G., \& Boon, C. (2005). Commonalities and contradictions in HRM and performance research. Human Resource Management Journal, 15: 67-94. EBSCOhost Business Source Complete. Accession Number: 17649112.

Bowen, D.E., \& Ostroff, C. (2004). Understanding HRM-Firm Performance Linkages: The Role of the "Strength" of the HRM System. The Academy of Management Review, 29, 203-221. doi:10.5465/AMR.2004.12736076.

Brayfield, A. H., \& Rothe, H.F. (1951). An Index of Job Satisfaction. Journal of Applied Psychology, 35, 307-311. doi: 10.1037/h0055617.

Brooke, P.P.J., Russell, D.W., \& Price, J.L. (1988). Discriminant Validation of Measures of Job Satisfaction, Job Involvement, and Organizational Commitment. Journal of Applied Psychology, 73: 139-145. doi: 10.1037/0021-9010.73.2.139.

Chatman, J.A. (1991). Matching People and Organizations: Selection and Socialization in Public Accounting Firms. Administrative Science Quarterly, 36: 459-484. doi: $10.2307 / 2393204$.

Chen, G., \& Bliese, P.D. (2002). The role of different levels of leadership in predicting selfand collective efficacy: Evidence for discontinuity. Journal of Applied Psychology, 87: 549-556. Doi:10.1037/0021-9010.87.3.549.

Coff, R. and Kryscynski, D. (2011). Drilling for micro-Foundations of Human-Capital Based Competitive Advantages. Journal of Management, 37: 1429-1443.

Cooper-Thomas, H., Gardner, D., O’Driscoll, M., Catley, B., Bentley, T., Trenberth, L. (2013). Neutralizing workplace bullying: the buffering effects of contextual factors. Journal of Managerial Psychology, 28: 384-407. 
Coyle-Shapiro, J., \& Conway, N. (2004). The employment relationship through the lens of social exchange. In Coyle-Shapiro, J., Shore, L.M., Taylor, S., \& Tetrick, L. (eds). The Employment Relationship: Examining Psychological and Contextual Perspectives. Oxford, UK: Oxford University Press.

Crane, S., Sloane, P.D., Elder, N., Cohen, L., Laughtenschlaeger, N., Walsh, K., \& Zimmerman, S. (2015). Reporting and Using Near-miss Events to Improve Patient Safety in Diverse Primary Care Practices: A Collaborative Approach to Learning from Our Mistakes. Journal of the American Board of Family Medicine, 28: 452-460. doi: 10.3122/jabfm.2015.04.140050.

D’Cruz, P., Noronha, E., \& Beale, D. (2014). The workplace bullying-organizational change interface: Emerging challenges for human resource management. International Journal of Human Resource Management, 25: 1434-1459. doi:10.1080/09585192.2013.870314.

Datta, D.K., Guthrie, J.P., \& Wright, P.M. (2005). Human Resource Management and Labor Productivity: Does Industry Matter? Academy of Management Journal, 48: 135-145. doi: 10.5465/AMJ.2005.15993158.

Djurkovic, N., McCormack, D., \& Casimir, G. (2008). Workplace bullying and intention to leave: the moderating effect of perceived organizational support. Human Resource Management Journal, 18: 405-422. 10.1111/j.1748-8583.2008.00081.x.

Edwards, J.R., \& Lambert, L.S. (2007). Methods for Integrating Moderation and Mediation: A General Analytical Framework Using Moderated Path Analysis. Psychological Methods, 12: 1-22. doi: 10.1037/1082-989X.12.1.1.

Ehrhart, M.G., \& Naumann, S.E. (2004). Organizational citizenship behaviour in work groups: A group norms approach. Journal of Applied Psychology, 89: 960-974.doi: 10.1037/0021-9010.89.6.960.

Ehrnrooth, M., \& Bjorkman, I. (2012). An integrative HRM process theorization: Beyond signalling effects and mutual gains. Journal of Management Studies, 49: 1109-1135. Doi: 11.1111/j.1467-6486.2012.01055.x.

Einarsen, S., Hoel, H., \& Notelaers, G. (2009). Measuring exposure to bullying and harassment at work: Validity, factor structure and psychometric properties of the Negative Acts Questionnaire-Revised. Work \& Stress, 23: 24-44.

Einarsen, S., \& Skogstad, A. (1996). Bullying at work: Epdemilogical findings in public and private organizations. European Journal of Work and Organizational Psychology, 5: 185-202.

Einarsen, S., Hoel, H., Zapf, D., \& Cooper, C. L. (2003). The concept of bullying at work The European tradition. In S. Einarsen, H. Hoel, D. Zapf, \& C. L. Cooper (Eds.), Bullying and Emotional Abuse in the Workplace - International perspectives in research and practice (pp. 3-30). London: Taylor \& Francis.

Einarsen, S., Raknes, B.I., \& Mattiesen, S.B. (1994). Bullying and harassment at work and their relationships to work environment quality: An exploratory study. European Work and Organizational Psychologist, 4, 381-401. doi: 10.1080/135494329408410497.

Giga, S.I., Hoel, H., \& Lewis, D. (2008). The Costs of Workplace Bullying. London: United the union/Department for Business, Enterprise and Regulatory Reform.

Guest, D., \& Conway, N. (2011). The impact of HR practices, HR effectiveness and a 'strong HR system' on organisational outcomes: A stakeholder perspective. The International Journal of Human Resource Management, 22: 1686-1702. doi:10.1080/09585192.2011.565657.

Guest, D.E. (2011). Human resource management and performance: still searching for some 
answers. Human Resource Management Journal, 21: 3-13. doi: 10.1111/j.1748 $-8583.2010 .00164$

Hauge, L.J., Skogstad, A., \& Einarsen, S. (2010). The relative impact of work place bullying as a social stressor at work. Scandinavian Journal of Psychology, 51: 426-433. doi: $10.1111 / \mathrm{j} .1467$.

Hoel, H. \& Giga, S.I. (2006). Destructive interpersonal conflict in the workplace: The effectiveness of management interventions. British Occupational Health Research Foundation (BOHRF) and Manchester Business School, The University of Manchester, Manchester.

Hofmann, D., Griffin, M., \& Gavin, M. (2000). The application of hierarchical linear modelling to organizational research. In Klein, K., \& Kozlowski, S. (eds). Multilevel Theory, Research, and Methods in Organizations: Foundations, Extensions and New Directions. (pp.467-511). San Francisco, CA: Jossey-Bass.

Hofmann, D.A. \& Gavin, M.B. (1998). Centering decisions in hierarchical linear models: Implications for research in organizations. Journal of Management, 24: 623-641. doi: 10.1177/014920639802400504.

Hogh, A., Hoel, H., and Carneiro, I.G. (2011). Bullying and employee turnover among healthcare workers: A three-wave prospective study. Journal of Nursing Management, 19: 742-751. doi: j.1365-2/34.2011.0124.x.

Holzer, H.J., Block, R.N., Cheatham, M., \& Knott, J.H. (1993). Are training subsidies for firms effective? The Michigan experience. ILR Review, 46: 625-636. doi: 10.1177/001979399304600403.

Houshmand, M., O’Reilly, J., Robinson, S., \& Wolff, A. (2012). Escaping bullying: The simultaneous impact of individual and unit-level bullying on turnover intentions. Human Relations, 65: 901-918. doi: 10.1177/0018726712445100.

Huselid, M.A., Jackson, S.E., \& Schuler, R.S. (1997). Technical and Strategic Human Resources Management Effectiveness as Determinants of Firm Performance. The Academy of Management Journal, 40: 171-188. doi: 10.2307/257025.

Hutchinson, S., \& Purcell, J. (2010). Managing ward managers for roles in HRM in the NHS: overworked and under-resourced. Human Resource Management Journal, 20: 357-374. doi: 10.1111/j.1748-8583.2010.00141.

Jackson, D., Clare, J., \& Mannix, J. (2002). Who would want to be a nurse? Violence in the workplace - a factor in recruitment and retention. Journal of Nursing Management, 10: 13-20. doi: 10.1046/j.0966-0429.2001.00262.x.

Katou, A., Budhwar, P. \& Patel, C. (2014). Content vs. Process in the HRM-Performance relationship: An Empirical Examination. Human Resource Management, 53: 527-544.

Kenny, D., A., Kashy, D., \& Bolger, N. (1998). Data analysis in social psychology. In Gilbert, d., Fiske, S.,\& Lindzey, G. (Eds). Handbook of Social Psychology, (4 ${ }^{\text {th }}$, pp.233-265). New York: McGraw-Hill.

Khilji, S.E., \& Wang, X. (2006). 'Intended' and 'implemented' HRM: the missing linchpin in strategic human resource management research. The International Journal of Human Resource Management, 17: 1171-1189. EBSCOhost Business Source Complete. Accession Number: 21782009.

Kline, R. (2005). Principles and Practices of Structural Equation Modelling. (2 ${ }^{\text {nd }}$ ed.) New York: Guilford Press.

Kozlowski, S.W., \& Klein, K.J. (2000). A multilevel approach to theory and research in organizations: Contextual, temporal, and emergent processes. In Klein, K.J., \& Kozlowski, S.W.J. (eds). Multilevel Theory, Research, and Methods in Organizations: Foundations, Extensions, and New Directions (pp.3-90). San Francisco, CA: JosseyBass. 
Krueger, A., \& Rouse, C. (1998). The effect of workplace education on earnings, turnover, and job performance. Journal of Labour Economics, 16: 61-94. doi: 10.1086/209882.

Laschinger, H.K.S. (2014). Impact of Workplace Mistreatment on Patient Safety Risk and Nurse-Assessed Patient Outcomes. The Journal of Nursing Administration, 44: 284290. doi: 10.1097/NNA.0000000000000068.

Lee, R., \& Brotheridge, C.M. (2006). When prey turns predatory: Workplace bullying as a predictor of counter-aggression, bullying, coping and wellbeing. European Journal of Work and Organizational Psychology, 15: 352-377. http://dx.doi.org/10.1080/13594320600636531.

Leon-Pérez, J.M., Arenas, A., \& Butts, T. (2012). Effectiveness of conflict management training to prevent workplace bullying. In N. Tehrani (ed.), Workplace bullying Symptoms and solutions (pp. 230-243). London: Routledge.

Liao, H., Toya, K., Lepak, D.P., \& Hong, Y. (2009). Do They See Eye to Eye? Management and Employee Perspectives of High-Performance Work Systems and Influence Processes on Service Quality. Journal of Applied Psychology, 94: 371-391. doi: 10.1037/a0013504.

MacKinnon, D.P., Lockwood, C.M., Hoffman, J.M., West, S.G., \& Sheets, V. (2002). A Comparison of Methods to Test Mediation and Other Intervening Variable Effects. Psychological Methods, 7: 83-104. doi: 10.1037/1082-989X.7.1.83.

Mathisen, G.E., Einarsen, S., \& Mykletun, R. (2008). The occurrences and correlates of bullying and harassment in the restaurant sector. Scandinavian Journal of Psychology, 49: 59-68. doi: 10.1111/j.1467.-9450.2007.00602.x.

McVicar, A. (2003). Workplace stress in nursing: A literature review. Journal of Advanced Nursing, 44: 633-642. doi10.1046/j.0309-2402.203.02853.

Mikkelsen, E., Hogh, A., \& Puggaard, L. (2011). Prevention of bullying and conflicts at work: process factors influencing the implementation and effects of interventions. International Journal of Workplace Health Management, 4: 84-100.

Muller, D., Judd, C.M., \& Yzerbyt, V.Y. (2005). When moderation is mediated and mediation is moderated. Journal of Personality and Social Psychology, 89: 852-863. doi: 10.1037/0022-3514.89.6.852.

Ng, K.Y., Ang, S., \& Chan, K.Y. (2008). Personality and leader effectiveness: a moderated mediation model of leadership self-efficacy, job demands and job autonomy. Journal of Applied Psychology, 93: 733-743. doi: 10.1037/0021-9010.93.4.733.

Nielsen, M. B., Skogstad, A., Matthiesen, S. B., Glasø, L., Aasland, M. S., Notelaers, G., \& Einarsen, S. (2009). Prevalence of workplace bullying in Norway: Comparisons across time and estimation methods. European Journal of Work and Organizational Psychology, 18: 81-101.

Nielsen, M.B., Mageroy, N., Gjerstad, J., \& Einarsen, S. (2014). Workplace bullying and subsequent health problems. Tidsskr Nor Laegeforen, 134: 1233-1238. doi: 10.4045/tidsskr.13.0880.

Nishii, L.H., Lepak, D.P., \& Schneider, B. (2008). Employee attributions of the 'why' of HR practices: Their effects on employees' attitudes and behaviours, and customer satisfaction. Personnel Psychology, 61: 503-545. doi: 10.1111/j.17446570.2008.00121.

Notelaers G., Baillien E., De Witte H., Einarsen S., Vermunt J. K. Testing the strain hypothesis of the demand control model to explain severe bullying at work. Economic and Industrial Democracy. 2012: 69-87. doi: 10.1177/0143831X12438742.

Ostroff, C., \& Bowen, D.E. (2016). Reflections on the 2014 decade award: Is there strength in the construct of HR system strength. Academy of Management Review, 41: 196-214. doi: 10.5464/amr.2015.0323. 
Pituch, K.A., Whittaker, T.A., \& Stapleton, L.M. (2005). A comparison of methods to test for mediation in multisite experiments. Multivariate Behavioural Research, 40: 1-23. doi: 10.1207/s15327906mbr4001_1.

Podsakoff, P.H., MacKenzie, S.B., Lee, J., \& Podsakoff, N.P. (2003). Common method biases in behavioural research: A critical review of literature and recommended remedies. Journal of Applied Psychology, 88: 879-903. doi: 10.1037/0021-9010.88.5.879.

Preacher, K.J., Rucker, D.D., \& Hayes, A.F. (2007). Addressing moderated mediation hypotheses: Theory, methods, and prescriptions. Multivariate Behavioral Research, 42: 485-227.

Purcell, J., Kinnie, N., Hutchinson, S., Rayton, B., \& Swart, J. (2003). Understanding the People and Performance Link: Unlocking the black box. London: Chartered Institute of Personnel and Development.

Quine, L. (1999). Workplace bullying in NHS community trust: Staff questionnaire survey. British Medical Journal, 318(7178): 228-232.

Raudenbush, S.W., Bryk, A.S., Cheong, Y.F., Congdon, R.T., \& Du Toit, M. (2004). HLM6: Hierarchical Linear and NonLinear Modelling. Lincolnwood, IL: Scientific Software International.

Rodríguez-Muñoz, A., Baillien, E., De Witte, H., Moreno-Jiménez, B., \& Pastor, J.C. (2009). Cross-lagged relationships between workplace bullying, job satisfaction and engagement: Two longitudinal studies. Work \& Stress, 23: 225-243. doi: 10.1080/02678370903227357.

Rodríguez-Muñoz, A., Baillien, E., De Witte, H., Moreno-Jiménez, B., \& Pastor, J.C. (2009). Cross-lagged relationships between workplace bullying, job satisfaction and engagement: Two longitudinal studies. Work \& Stress, 23: 225-243. doi: 10.1080/02678370903227657.

Rogerson, P.A. (2001). Statistical Methods for Geography. London: Sage.

Russo, S.D., Mascia, D., \& Morandi, F. (2016). Individual perceptions of HR practices, HRM strength and appropriateness of care: A meso, multilevel approach. International Journal of Human Resource Management. doi: 10.1080/09585192.2016.1165276.

Samnani, A., \& Singh, P. (2014). Performance-enhancing compensation practices and employee productivity: The role of workplace bullying. Human Resource Management Review, 24: 5-16. doi.org/10.1016/j.hrmr.2013.08.013.

Samnani, A.K., \& Singh, P. (2012). 20 Years of workplace bullying research: A review of the antecedents and consequences of bullying in the workplace. Aggression and Violent Behavior, 17, 581-589. doi: http://dx.doi.org/10.1016/j.avb.2012.08.004.

Selig, J.P., \& Preacher, K., J. (2008). Monte Carlo method for assessing mediation: An interactive tool for creating confidence intervals for indirect effects. Access online http://quantpsy.org/. Retrieved on $31^{\text {st }}$ Oct 2016.

Shen, J. (2015). Principles and Applications of Multilevel Modeling in Human Resource Management Research. Human Resource Management. doi: 10.1002/hrm.21666.

Skogstad, A., Torsheim, T., Einarsen, S., \& Hauge, L.J. (2011). Testing the work environment hypothesis of bullying on a group level of analysis: Psychological factors as precursors of observed workplace bullying. Applied Psychology, 60: 475-495. doi: 10.1111/j.1464-0597.2011.00444.x.

Snijders, T.A.B., \& Bosker, R.J. (1999). Multilevel Analysis: An Introduction to Basic and Advanced Multilevel Modeling. Cornwall: Sage Publications.

Sobel, M.E. (1982). Asymptotic intervals for indirect effects in structural equations models. In Leinhart, S. (eds). Sociological Methodology, (pp.290-312). San Francisco: JosseyBass. 
Sparrow, P. R., \& Makram, H. (2015). What is the value of talent management? Building valuedriven processes within a talent management architecture. Human Resource Management Review. doi: 10.1016/j.hrmr.2015.04.002.

Spector, P.E. (2006). Method variance in organizational research: Truth or urban legend? Organizational Research methods, 9: 221-232. doi: 10.1177/1094428105284955.

Spector, P. E., \& Fox, S. (2002). An emotion-centered model of voluntary work behavior: Some parallels between counterproductive work behavior (CWB) and organizational citizenship behavior (OCB). Human Resource Management Review, 12, 269-292.

Tsui, A.S. (1987). Defining the Activities and Effectiveness of the Human Resource Department: A Multiple Constituency Approach. Human Resource Management, 26, 35-69. doi: 10.1002/hrm.3930260104.

Van Woerkom, M., \& Meyers, M.C. (2015). My strengths count! Effects of a strengths-based psychological climate on positive affect and job performance. Human Resource Management, 54, 81-103. doi: 10.1002/hrm.21623.

Woodrow, C., \& Guest, D.E. (2016). Leadership and Approaches to the Management of Workplace Bullying. European Journal of Work and Organizational Psychology, 21, 1-13. doi: 10.1080/1359432X.2016.1243529.

Woodrow, C., \& Guest, D.E. (2014). When good HR gets bad results: exploring the challenge of HR implementation in the case of workplace bullying. Human Resource Management Journal, 24, 38-56. doi: 10.1111/1748-8583.12021.

Wright, P.M., \& Nishii, L.H. (2006). Strategic HRM and Organizational Behavior: Integrating Multiple Levels of Analysis (Working Paper No. \#06-05). Ithaca, NY: Cornell University, School of Industrial and Labor Relations, Centre for Advanced Human Resource Studies.

Zapf, D., Escartin, J., Einarsen, S., Hoel, H., \& Vartia, M. (2011). Empirical findings on prevalence and risk groups of bullying in the workplace. In Einarsen, S., Hoel, H., Zapf, D., \& Cooper. C. (eds). Bullying and Harassment in the Workplace: Developments in Theory, Research and Practice ( $2^{\text {nd }}$ Ed) (pp.75-106). Boca Raton, FL: CRC Press.

Zohar, D., \& Luria, G. (2010). Group leaders as gatekeepers: Testing safety climate variations across levels of analysis. Applied Psychology, 59: 647-673. 
Table 1

Means, Standard deviations and correlations for study variables

\begin{tabular}{|c|c|c|c|c|c|c|c|c|c|c|c|}
\hline Construct & Mean & SD & V1 & V2 & V3 & V4 & V5 & V6 & V7 & V8 & V9 \\
\hline \multicolumn{12}{|l|}{ Individual Level } \\
\hline $\begin{array}{l}\text { V1 Gender } \\
\text { (female) }\end{array}$ & 0.89 & 0.49 & & & & & & & & & \\
\hline V2 Tenure & 1.92 & 1.03 & 0.12 & & & & & & & & \\
\hline $\begin{array}{l}\text { V3 Employment } \\
\text { Status } \\
\text { (permanent) }\end{array}$ & 1.62 & 0.40 & 0.03 & 0.14 & & & & & & & \\
\hline $\begin{array}{l}\text { V4 Trade Union } \\
\text { Member }\end{array}$ & 0.91 & 0.10 & 0.08 & 0.12 & 0.10 & & & & & & \\
\hline $\begin{array}{l}\text { V5 Perceived } \\
\text { Effectiveness of } \\
\text { Implementation } \\
\text { (Process) of BPPs }\end{array}$ & 3.02 & 0.70 & 0.05 & 0.08 & 0.11 & -0.09 & & & & & \\
\hline $\begin{array}{l}\text { V6 Bullied past } 6 \\
\text { months }\end{array}$ & 0.53 & 0.47 & 0.04 & 0.06 & 0.12 & $-0.23 * * *$ & $-0.35 * * *$ & & & & \\
\hline $\begin{array}{l}\text { V7 Job } \\
\text { Satisfaction }\end{array}$ & 2.97 & 1.98 & 0.07 & $0.17 *$ & $0.23 * * *$ & 0.11 & $0.25^{* * *}$ & $-0.46 * * *$ & & & \\
\hline $\begin{array}{l}\text { V8 Intended } \\
\text { Turnover }\end{array}$ & 3.06 & 1.23 & 0.11 & $-0.015^{*}$ & $-0.17 *$ & $-0.14 *$ & $-0.26^{* *}$ & $0.53 * * *$ & $-0.17 *$ & & \\
\hline $\begin{array}{l}\text { V9 Mistakes/near } \\
\text { misses in patient } \\
\text { care }\end{array}$ & 2.25 & 1.62 & $\begin{array}{l}0.03 \\
\end{array}$ & -0.09 & 0.11 & -0.08 & $-0.19 * *$ & $0.31 * * *$ & -0.05 & 0.13 & \\
\hline $\begin{array}{l}\text { Organisational } \\
\text { Level }\end{array}$ & & & V10 & V11 & V12 & V13 & V14 & V15 & & & \\
\hline V10 ln (Org Size) & 1.82 & 0.62 & & & & & & & & & \\
\hline $\begin{array}{l}\text { V11 Ownership } \\
\text { (private) }\end{array}$ & 0.27 & 0.11 & $\begin{array}{l}-0.08 \\
\end{array}$ & & & & & & & & \\
\hline $\begin{array}{l}\text { V12 Number of } \\
\text { HPWPs practices }\end{array}$ & 0.13 & 2.25 & $0.17 *$ & 0.09 & & & & & & & \\
\hline $\begin{array}{l}\text { V13 Number of } \\
\text { best practice anti- } \\
\text { bullying policies } \\
\text { \& practices } \\
\text { (NBPPs): } \\
\text { (Content) }\end{array}$ & 0.33 & 4.67 & $0.18 *$ & 0.08 & $0.22 * *$ & & & & & & \\
\hline
\end{tabular}




\begin{tabular}{|l|l|l|l|l|l|l|l|l|l|l|}
\hline $\begin{array}{l}\text { V14 Targeted } \\
\text { Training } \\
\text { incidence }\end{array}$ & 2.21 & 2.56 & 0.12 & 0.07 & $0.15^{*}$ & $0.14^{*}$ & & & \\
\hline $\begin{array}{l}\text { V15 Targeted } \\
\text { training hours per } \\
\text { manager }\end{array}$ & 0.25 & 0.45 & 0.11 & 0.08 & $0.14^{*}$ & $0.13^{*}$ & $0.43^{* * *}$ & & \\
\hline $\begin{array}{l}\text { V16 Resources on } \\
\text { targeted training }\end{array}$ & 2.95 & 2.80 & 0.10 & 0.09 & $0.15^{*}$ & $0.12^{*}$ & $0.38^{* * *}$ & $0.46^{* * *}$ & \\
\hline
\end{tabular}

Note. ${ }^{*} \mathrm{p}<0.05 ;{ }^{* *} \mathrm{p}<0.01$ and ${ }^{* * *} \mathrm{p}<0.001$ (one-tailed t-tests) 
Table 2

Intended and Effectively Implemented Practices, Targeted Training and the Probability of Bullying: Mixed Effects Multi-Level Logistical Regressions

\begin{tabular}{|c|c|c|c|c|c|}
\hline Variables & $\begin{array}{c}\text { Null Model } \\
\text { B (SE) }\end{array}$ & $\begin{array}{c}\text { Model } 2 \\
B(\mathrm{SE})\end{array}$ & $\begin{array}{c}\text { Model } 3 \\
B(\mathrm{SE})\end{array}$ & $\begin{array}{c}\text { Model } 4 \\
B(\mathrm{SE})\end{array}$ & $\begin{array}{c}\text { Model } 5 \\
B(\mathrm{SE})\end{array}$ \\
\hline \multicolumn{6}{|l|}{$\begin{array}{l}\text { Fixed Effects: Individual level } \\
\text { (Level 1) }\end{array}$} \\
\hline Intercept & $-2.45 * * *(0.14)$ & $-2.06 * * *(0.16)$ & $-2.48 * * *(0.10)$ & $-2.03 * * *(0.16)$ & $-2.04 * * *(0.15)$ \\
\hline Gender & & $1.14(0.71)$ & $1.14(0.72)$ & $1.14(0.71)$ & $1.14(0.70)$ \\
\hline Tenure & & $0.72(0.43)$ & $0.73(0.44)$ & $0.72(0.43)$ & $0.72(0.43)$ \\
\hline Employment status & & $0.72(0.48)$ & $0.73(0.48)$ & $0.72(0.48)$ & $0.71(0.47)$ \\
\hline Trade Union Member & & $-1.60 * *(0.72)$ & $-1.60 * *(0.73)$ & $-1.60 * *(0.72)$ & $-1.59 * *(0.72)$ \\
\hline \multicolumn{6}{|l|}{$\begin{array}{l}\text { Random Effects: } \\
\text { Organisational level } \\
\text { (Level 2) } \\
\end{array}$} \\
\hline $\ln$ (Organisational Size) & & & $1.58 *(0.83)$ & $1.58 *(0.82)$ & $1.58 *(0.83)$ \\
\hline Sector & & & $-0.15^{*}(0.06)$ & $-0.14 *(0.06)$ & $-0.13 *(0.06)$ \\
\hline Number HPWPs & & & $-0.57(0.38)$ & $-0.57(0.38)$ & $-0.56(0.39)$ \\
\hline \multicolumn{6}{|l|}{$\begin{array}{l}\text { Organisational level (Level 2): } \\
\text { Explanatory Variables }\end{array}$} \\
\hline NBPPs & & & & $-1.11(0.69)$ & \\
\hline \multicolumn{6}{|l|}{$\begin{array}{l}\text { Individual level (Level 1): } \\
\text { Explanatory Variables }\end{array}$} \\
\hline $\begin{array}{l}\text { Perceived Effectiveness of } \\
\text { Implementation (BPPs) }\end{array}$ & & & & & $-2.27 * *(0.93)$ \\
\hline $\begin{array}{l}\text { Variance Components } \\
\text { Individual level (Level-1) } \\
\text { Organisational level (Level-2) }\end{array}$ & $\begin{array}{l}0.112(0.025) \\
0.153(0.026)\end{array}$ & $\begin{array}{l}0.110(0.024) \\
0.152(0.025)\end{array}$ & $\begin{array}{l}0.110(0.024) \\
0.152(0.025)\end{array}$ & $\begin{array}{l}0.110(0.024) \\
0.150(0.023)\end{array}$ & $\begin{array}{l}0.110(0.024) \\
0.152(0.025)\end{array}$ \\
\hline Model Deviance & 1698.22 & 1563.22 & 1145.67 & 900.26 & 676.67 \\
\hline
\end{tabular}

Note 1. Standardised logit regression estimates with robust standard errors reported in parenthesis; estimated by Mixed Effects Multi-Level Logistical (Stata 13)

Note 2. ${ }^{*} \mathrm{p}<0.05 ;{ }^{* *} \mathrm{p}<0.01 ;{ }^{* *} \mathrm{p}<0.001$ (one-tailed tests)

Note 3. Group variable $=47$; Number of observations $=1,507$; Obs per group: $\min =30$ avg $=32 \max =40$ 
Table 3

HLM Results for associations between workplace bullying, effective implementation, targeted training \& employee outcomes: Job Satisfaction (JS)

\begin{tabular}{|c|c|c|c|c|c|c|c|c|c|c|c|c|}
\hline Variables & $\begin{array}{c}\text { Null Model } \\
\text { JS } \\
\text { B (SE) }\end{array}$ & $\begin{array}{c}\text { Model } 2 \\
\text { JS }\end{array}$ & $\begin{array}{l}\text { Model } 3 \\
\text { JS }\end{array}$ & $\begin{array}{c}\text { Model } 4 \\
\text { JS }\end{array}$ & $\begin{array}{c}\text { Model } 5 \\
\text { JS }\end{array}$ & $\begin{array}{c}\text { Model } 6 \\
\text { JS }\end{array}$ & $\begin{array}{c}\text { Model } 7 \\
\text { JS }\end{array}$ & $\begin{array}{c}\text { Model } 8 \\
\text { JS }\end{array}$ & $\begin{array}{c}\text { Model } 9 \\
\text { JS }\end{array}$ & $\begin{array}{l}\text { Model } 10 \\
\text { JS }\end{array}$ & $\begin{array}{c}\text { Model } 11 \\
\text { JS }\end{array}$ & $\begin{array}{c}\text { Model } 12 \\
\text { JS }\end{array}$ \\
\hline Intercept & $2.80 * * *(0.11)$ & $2.43^{* * *}(0.10)$ & $2.39 * * *(0.11)$ & $2.50 * * *(0.12)$ & $2.48^{* * *}(0.11)$ & $2.47^{* * *}(0.10)$ & $2.48^{* * *}(0.11)$ & $2.49 * * *(0.11)$ & $2.48^{* * *}(0.10)$ & $2.49 * * *(0.11)$ & $2.47 * * *(0.10)$ & $2.46^{* * *}(0.11)$ \\
\hline $\begin{array}{l}\text { Individual level } \\
\text { (Level 1): } \\
\text { Control } \\
\text { Variables }\end{array}$ & & & & & & & & & & & & \\
\hline Gender & & $0.07(0.06)$ & $0.07(0.06)$ & $0.07(0.06)$ & $0.06(0.05)$ & $0.06(0.06)$ & $0.07(0.06)$ & $0.07(0.05)$ & $0.07(0.05)$ & $0.06(0.04)$ & $0.06(0.04)$ & $0.06(0.04)$ \\
\hline Tenure & & $0.15^{*}(0.08)$ & $0.16^{*}(0.08)$ & $0.16 *(0.08)$ & $0.16 *(0.08)$ & $0.16^{* *}(0.07)$ & $0.15 *(0.08)^{*}$ & $0.16 *(0.07)$ & $0.15 *(0.07)$ & $0.15 *(0.07)$ & $0.14 *(0.06)$ & $0.14 *(0.06)$ \\
\hline $\begin{array}{l}\text { Employment } \\
\text { status }\end{array}$ & & $0.10 *(0.08)$ & $0.11^{*}(0.06)$ & $0.11 *(0.06)$ & $0.11^{*}(0.06)$ & $0.11 *(0.06)$ & $0.12 *(0.06)$ & $0.12 *(0.06)$ & $0.12 *(0.06)$ & $0.13^{*}(0.07)$ & $0.13^{*}(0.07)$ & $0.13 *(0.07)$ \\
\hline $\begin{array}{l}\text { Trade Union } \\
\text { Member }\end{array}$ & & $0.12 *(0.05)$ & $0.11^{*}(0.06)$ & $0.10^{*}(0.05)$ & $0.11^{*}(0.06)$ & $0.11^{*}(0.06)$ & $0.11^{*}(0.06)$ & $0.11 *(0.06)$ & $0.11 *(0.06)$ & $0.10^{*}(0.05)$ & $0.10 *(0.05)$ & $0.11 *(0.06)$ \\
\hline $\begin{array}{l}\text { Organisational } \\
\text { level (Level 2): } \\
\text { Control } \\
\text { Variables } \\
\end{array}$ & & & & & & & & & & & & \\
\hline $\begin{array}{l}\ln (\text { Organisational } \\
\text { Size) }\end{array}$ & & & $-0.11 * *(0.05)$ & $-0.11 * *(0.05)$ & $\begin{array}{l}-0.11^{* * * *} \\
(0.05) \\
\end{array}$ & $-0.10^{* *}(0.05)$ & $-0.10 * *(0.05)$ & $-0.10 * *(0.05)$ & $-0.11^{* *}(0.05)$ & $-0.11^{* *}(0.05)$ & $-0.11 * *(0.05)$ & $-0.11^{* *}(0.05)$ \\
\hline Private Sector & & & $0.08 *(0.04)$ & $0.08 *(0.04)$ & $0.07 *(0.04)$ & $0.07 *(0.03)$ & $0.08 *(0.04)$ & $0.08 *(0.04)$ & $0.07 *(0.03)$ & $0.08 *(0.04)$ & $0.08 *(0.04)$ & $0.08 *(0.04)$ \\
\hline Number HPWPs & & & $0.19 * *(0.08)$ & $0.17^{* *}(0.07)$ & $0.16 * *(0.07)$ & $0.16^{* *}(0.07)$ & $0.17^{* *}(0.08)$ & $0.17^{* *}(0.07)$ & $0.16^{* *}(0.07)$ & $0.16^{* *}(0.07)^{*}$ & $0.17^{* *}(0.08)$ & $0.17^{* *}(0.08)$ \\
\hline NBPPs & & & $0.15 *(0.08)$ & $0.15 *(0.08)$ & $0.15 *(0.08)$ & $0.15^{*}(0.07)$ & $0.16 *(0.08)$ & $0.15 *(0.08)$ & $0.16 *(0.08)$ & $0.15 *(0.08)$ & $0.16 *(0.09)$ & $0.16 *(0.09)$ \\
\hline $\begin{array}{l}\text { Level } 2 \\
\text { Explanatory } \\
\text { Variables }\end{array}$ & & & & & & & & & & & & \\
\hline $\begin{array}{l}\text { Targeted } \\
\text { Training } \\
\text { Incidence (TT-I) }\end{array}$ & & & & & & & $0.29 * * *(0.12)$ & & & & & \\
\hline $\begin{array}{l}\text { Targeted } \\
\text { Training Hours } \\
\text { (TT-H) }\end{array}$ & & & & & & & & $0.18^{*}(0.09)$ & & & & \\
\hline $\begin{array}{l}\text { Targeted } \\
\text { Training } \\
\text { Resources } \\
\text { (TTR) }\end{array}$ & & & & & & & & & $0.23^{* *}(0.10)$ & & & \\
\hline
\end{tabular}




\begin{tabular}{|c|c|c|c|c|c|c|c|c|c|c|c|c|}
\hline $\begin{array}{l}\text { Level 1 } \\
\text { Explanatory } \\
\text { Variables } \\
\end{array}$ & & & & & & & & & & & & \\
\hline $\begin{array}{l}\text { Bullied past } 6 \\
\text { months }\end{array}$ & & & & $\begin{array}{l}-0.35^{* * * *} \\
(0.10)\end{array}$ & & $-0.17 *(0.09)$ & $-0.18 *(0.09)$ & $-0.17 *(0.09)$ & $-0.17 *(0.08)$ & $-0.18 *(0.09)$ & $-0.17 *(0.09($ & $-0.18 *(0.09)$ \\
\hline $\begin{array}{l}\text { Perceived } \\
\text { Effectiveness of } \\
\text { Implementation } \\
\text { (BPPs) }\end{array}$ & & & & & $0.38 * * *(0.11)$ & $0.35 * * *(0.10)$ & $0.34^{* * *}(0.11)$ & $0.32 * * *(0.09)$ & $0.33^{* * *}(0.10)$ & $0.33^{* * *}(0.09)$ & $0.33^{* * *}(0.10)$ & $0.32^{* * *}(0.10)$ \\
\hline $\begin{array}{l}\text { Cross-Level } \\
\text { Interaction: } \\
\text { TT-I * Perceived } \\
\text { Effective } \\
\text { Implementation } \\
\text { (BPPs) }\end{array}$ & & & & & & & & & & $0.18^{* *}(0.08)$ & & \\
\hline $\begin{array}{l}\text { TT-H * Perceived } \\
\text { Effective } \\
\text { Implementation }\end{array}$ & & & & & & & & & & & $0.11 *(0.06)$ & \\
\hline $\begin{array}{l}\text { TT-R * Perceived } \\
\text { Effective } \\
\text { Implementation }\end{array}$ & & & & & & & & & & & & $0.14 *(0.07)$ \\
\hline Pseudo- $R^{2}$ & & 0.22 & 0.41 & 0.52 & 0.53 & 0.56 & 0.58 & 0.57 & 0.58 & 0.63 & 0.60 & 0.63 \\
\hline $\begin{array}{l}\text { Variance } \\
\text { Components } \\
\text { Individual level } \\
\text { (Level-1) } \\
\text { Organisational } \\
\text { level (Level-2) }\end{array}$ & $\begin{array}{l}0.528(0.026) \\
0.301(0.025)\end{array}$ & $\begin{array}{l}0.520(0.025) \\
0.297(0.023)\end{array}$ & $\begin{array}{l}0.517(0.023) \\
0.291(0.021)\end{array}$ & $\begin{array}{l}0.517(0.023) \\
0.291(0.021)\end{array}$ & $\begin{array}{l}0.517(0.023) \\
0.291(0.021)\end{array}$ & $\begin{array}{l}0.517(0.023) \\
0.291(0.021\end{array}$ & $\begin{array}{l}0.517(0.023) \\
0.291(0.021)\end{array}$ & $\begin{array}{l}0.517(0.023) \\
0.291(0.021)\end{array}$ & $\begin{array}{l}0.517(0.023) \\
0.291(0.021)\end{array}$ & $\begin{array}{l}0.517(0.023) \\
0.291(0.021)\end{array}$ & $\begin{array}{l}0.517(0.023) \\
0.291(0.021)\end{array}$ & $\begin{array}{l}0.517(0.023) \\
0.291(0.021)\end{array}$ \\
\hline Model Deviance & 1437.22 & 1232.77 & 1045.67 & 876.22 & 665.78 & 662.78 & 623.56 & 625.77 & 619.22 & 489.25 & 500.67 & 487.22 \\
\hline
\end{tabular}

Note 1. Unstandardized estimates (based on grand-mean-centring) are reported, with standard errors in parentheses.

Note 2. Group variable = 47; Number of observations = 1,507; Obs per group: $\min =30 \mathrm{avg}=32 \max =40$

Note 3. Pseudo $\mathrm{R}^{2}$ values estimate the amount of total variance (both level 1 and level 2) in the dependent variable captured by the predictors in the model.

Note 4. ${ }^{*} \mathrm{p}<0.05 ;{ }^{* *} \mathrm{p}<0.01 ;{ }^{* * *} \mathrm{p}<0.001$ (one-tailed tests) 
Table 4

HLM Results for associations between workplace bullying, effective implementation, targeted training \& employee outcomes: Intended

Turnover

\begin{tabular}{|c|c|c|c|c|c|c|c|c|c|c|c|c|}
\hline Variables & $\begin{array}{c}\text { Null Model } \\
\text { Intended } \\
\text { Turnover } \\
B(\mathrm{SE})\end{array}$ & $\begin{array}{l}\text { Model } 2 \\
\text { Intended } \\
\text { Turnover }\end{array}$ & $\begin{array}{l}\text { Model } 3 \\
\text { Intended } \\
\text { Turnover }\end{array}$ & $\begin{array}{l}\text { Model } 4 \\
\text { Intended } \\
\text { Turnover }\end{array}$ & $\begin{array}{l}\text { Model } 5 \\
\text { Intended } \\
\text { Turnover }\end{array}$ & $\begin{array}{l}\text { Model } 6 \\
\text { Intended } \\
\text { Turnover }\end{array}$ & $\begin{array}{l}\text { Model } 7 \\
\text { Intended } \\
\text { Turnover }\end{array}$ & $\begin{array}{l}\text { Model } 8 \\
\text { Intended } \\
\text { Turnover }\end{array}$ & $\begin{array}{l}\text { Model } 9 \\
\text { Intended } \\
\text { Turnover }\end{array}$ & $\begin{array}{c}\text { Model } 10 \\
\text { Intended } \\
\text { Turnover }\end{array}$ & $\begin{array}{l}\text { Model } 11 \\
\text { Intended } \\
\text { Turnover }\end{array}$ & $\begin{array}{l}\text { Model } 12 \\
\text { Intended } \\
\text { Turnover }\end{array}$ \\
\hline $\begin{array}{l}\text { Individual level } \\
\text { (Level 1): } \\
\text { Control } \\
\text { Variables } \\
\end{array}$ & & & & & & & & & & & & \\
\hline Gender & & $0.06(0.10)$ & $0.07(0.10)$ & $0.06(0.10)$ & $0.06(0.09)$ & $0.06(0.09)$ & $0.05(0.09)$ & $0.05(0.10)$ & $0.06(0.10)$ & $0.06(0.10)$ & $0.05(0.09)$ & $0.05(0.09)$ \\
\hline Tenure & & $-0.23 * *(0.09)$ & $-0.22 * *(0.09)$ & $-0.21 * *(0.09)$ & $-0.22 * *(0.10)$ & $-0.24 * *(0.10)$ & $-0.25^{* *}(0.10)$ & $-0.25 * *(0.10)$ & $-0.25 * *(0.10)$ & $-0.24 * *(0.10)$ & $-0.23 *(0.09)$ & $-0.24 *(0.10)$ \\
\hline $\begin{array}{l}\text { Employment } \\
\text { status }\end{array}$ & & $-0.16^{* *}(0.07)$ & $-0.15 *(0.08)$ & $-0.15 *(0.08)$ & $-0.15^{*}(0.07)$ & $-0.16 *(0.07)$ & $-0.15^{*}(0.08)$ & $-0.14 *(0.07)$ & $-0.14 *(0.07)$ & $-0.14 *(0.07)$ & $-0.14 *(0.07)^{*}$ & $-0.14^{*}(0.07)^{*}$ \\
\hline $\begin{array}{l}\text { Trade Union } \\
\text { Member }\end{array}$ & & $-0.19 * *(0.08)$ & $-0.17 *(0.09)$ & $-0.17 *(0.09)$ & $-0.16 *(0.08)$ & $-0.17 *(0.09)$ & $-0.16 *(0.08)$ & $-0.14 *(0.08)$ & $-0.14 *(0.07)$ & $-0.16 *(0.08)$ & $-0.16 *(0.08)$ & $-0.15 *(0.08)$ \\
\hline $\begin{array}{l}\text { Organisational } \\
\text { level (Level 2): } \\
\text { Control } \\
\text { Variables } \\
\end{array}$ & & & & & & & & & & & & \\
\hline $\begin{array}{l}\text { In(Organisational } \\
\text { Size) }\end{array}$ & & & $0.25 * *(0.10)$ & $0.25 * *(0.10)$ & $0.24 * *(0.10)$ & $0.23 * *(0.10)$ & $0.24^{* *}(0.10)$ & $0.23^{* *}(0.09)$ & $0.24 * *(0.10)$ & $0.24 * *(0.10)$ & $0.26^{* *}(0.10)$ & $0.25 * *(0.10)$ \\
\hline Private Sector & & & $-0.06 *(0.03)$ & $-0.06 *(0.03)$ & $-0.06 *(0.03)$ & $-0.06 *(0.03)$ & $-0.07 * *(0.03)$ & $-0.06 *(0.03)$ & $0.07 * *(0.03)$ & $-0.06 *(0.03)$ & $-0.07 *(0.03)$ & $-0.07 *(0.03)$ \\
\hline Number HPWPs & & & $-0.11 *(0.05)$ & $-0.10 *(0.05)$ & $-0.09 *(0.05)$ & $-0.10 *(0.05)$ & $-0.09 *(0.03)$ & $-0.10 *(0.05)$ & $-0.09 *(0.05)$ & $-0.09 *(0.05)$ & $-0.10 *(0.05)$ & $-0.10 *(0.05)$ \\
\hline NBPPs & & & $-0.08(0.06)$ & $-0.09(0.06)$ & $-0.08(0.05)$ & $-0.08(0.06)$ & $-0.09(0.06)$ & $-0.09(0.06)$ & $-0.08(0.06)$ & $-0.08(0.06)$ & $-0.07(0.05)$ & $-0.08(0.05)$ \\
\hline $\begin{array}{l}\text { Level } 2 \\
\text { Explanatory } \\
\text { Variables }\end{array}$ & & & & & & & & & & & & \\
\hline $\begin{array}{l}\text { Targeted } \\
\text { Training } \\
\text { Incidence (TT- } \\
\text { I) }\end{array}$ & & & & & & & $-0.16^{* *}(0.06)$ & & & & & \\
\hline $\begin{array}{l}\text { Targeted } \\
\text { Training Hours } \\
\text { (TT-H) }\end{array}$ & & & & & & & & $-0.09 *(0.05)$ & & & & \\
\hline $\begin{array}{l}\text { Targeted } \\
\text { Training }\end{array}$ & & & & & & & & & $-0.12 *(0.07)$ & & & \\
\hline
\end{tabular}




\begin{tabular}{|c|c|c|c|c|c|c|c|c|c|c|c|c|}
\hline $\begin{array}{l}\text { Resources } \\
\text { (TTR) }\end{array}$ & & & & & & & & & & & & \\
\hline $\begin{array}{l}\text { Level } 1 \\
\text { Explanatory } \\
\text { Variables }\end{array}$ & & & & & & & & & & & & \\
\hline $\begin{array}{l}\text { Bullied past } 6 \\
\text { months }\end{array}$ & & & & $0.45^{* * *}(0.14)$ & & $0.23^{* *}(0.11)$ & $0.22 * *(0.10)$ & $0.23^{* *}(0.10)$ & $0.22^{* *}(0.10)$ & $0.23^{* *}(0.10)$ & $0.22 * *(0.10)$ & $0.22 * *(0.10)$ \\
\hline $\begin{array}{l}\text { Perceived } \\
\text { Effectiveness of } \\
\text { Implementation } \\
\text { (BPPs) }\end{array}$ & & & & & $-0.24 * *(0.11)$ & $-0.22 * *(0.09)$ & $-0.22 * *(0.10)$ & $-0.20 *(0.10)$ & $-0.21^{* *}(0.10)$ & $-0.22 * *(0.10)$ & $-0.21 * *(0.10)$ & $0.20 *(0.10)$ \\
\hline $\begin{array}{l}\text { Cross-Level } \\
\text { Interaction: } \\
\text { TT-I * Perceived } \\
\text { Effective } \\
\text { Implementation } \\
\text { (BPPs) }\end{array}$ & & & & & & & & & & $-0.18 * *(0.08)$ & & \\
\hline $\begin{array}{l}\text { TT-H * } \\
\text { Perceived } \\
\text { Effective } \\
\text { Implementation }\end{array}$ & & & & & & & & & & & $-0.13 *(0.07)$ & \\
\hline $\begin{array}{l}\text { TT-R * } \\
\text { Perceived } \\
\text { Effective } \\
\text { Implementation }\end{array}$ & & & & & & & & & & & & $-0.10^{*}(0.05)$ \\
\hline Pseudo- $R^{2}$ & & 0.12 & 0.29 & 0.40 & 0.46 & 0.50 & 0.54 & 0.52 & 0.53 & 0.60 & 0.57 & 0.59 \\
\hline $\begin{array}{l}\text { Variance } \\
\text { Components } \\
\text { Individual level } \\
\text { (Level-1) }\end{array}$ & $0.422(0.022)$ & $0.418(0.019)$ & $0.415(0.018)$ & $0.415(0.018)$ & $0.415(0.018)$ & $0.415(0.018)$ & $0.415(0.018)$ & $0.415(0.018)$ & $0.415(0.018)$ & $0.415(0.018)$ & $0.415(0.018)$ & $0.415(0.018)$ \\
\hline $\begin{array}{l}\text { Organisational } \\
\text { level (Level-2) }\end{array}$ & $0.326(0.028)$ & $0.313(0.022)$ & $0.309(0.021)$ & $0.309(0.021)$ & $0.309(0.021)$ & $0.309(0.021)$ & $0.309(0.021)$ & $0.309(0.021)$ & $0.309(0.021)$ & $0.309(0.021)$ & $0.309(0.021)$ & $0.309(0.021)$ \\
\hline Model Deviance & 1625.78 & 1532.22 & 1505.67 & 1089.22 & 1132.76 & 1088.26 & 1029.61 & 1028.60 & 1029.28 & 1020.66 & 1031.24 & 1026.04 \\
\hline
\end{tabular}

Notes. See Table 3. 
Table 5

HLM Results for associations between individual-level bullying, employee outcomes \& practices: Near Misses \& Mistakes

\begin{tabular}{|c|c|c|c|c|c|c|c|c|c|c|c|c|}
\hline Intercept & $\begin{array}{c}\text { Null Model } \\
\text { JS } \\
B \text { (SE) }\end{array}$ & $\begin{array}{l}\text { Model } 2 \\
\text { Near Misses }\end{array}$ & $\begin{array}{c}\text { Model } 3 \\
\text { Near Misses }\end{array}$ & $\begin{array}{l}\text { Model } 4 \\
\text { Near Misses }\end{array}$ & $\begin{array}{l}\text { Model } 5 \\
\text { Near Misses }\end{array}$ & $\begin{array}{c}\text { Model } 6 \\
\text { Near Misses }\end{array}$ & $\begin{array}{c}\text { Model } 7 \\
\text { Near Misses }\end{array}$ & $\begin{array}{c}\text { Model } 8 \\
\text { Near Misses }\end{array}$ & $\begin{array}{l}\text { Model } 9 \\
\text { Near Misses }\end{array}$ & $\begin{array}{l}\text { Model } 10 \\
\text { Near Misses }\end{array}$ & $\begin{array}{c}\text { Model } 11 \\
\text { Near Misses }\end{array}$ & $\begin{array}{l}\text { Model } 12 \\
\text { Near Misses }\end{array}$ \\
\hline $\begin{array}{l}\text { Individual } \\
\text { level (Level 1): } \\
\text { Control } \\
\text { Variables } \\
\end{array}$ & $5.39 * * *(0.15)$ & $4.76^{* * * *}(0.26)$ & $4.80 * * *(0.25)$ & $4.84 * * *(0.25)$ & $4.98^{* * *}(0.25)$ & $4.81 * * *(0.23)$ & $4.82 * * *(0.22)$ & $4.88 * * *(0.28)$ & $4.93^{* * *}(0.28)$ & $4.96^{* * *}(0.29)$ & $4.89^{* * *}(0.25)$ & $4.78^{* * *}(0.24)$ \\
\hline Gender & & $0.02(002)$ & $0.03(0.03)$ & $0.04(0.03)$ & $0.04(0.03)$ & $0.04(0.03)$ & $0.04(0.03)$ & $0.04(0.03)$ & $0.04(0.03)$ & $0.04(0.03)$ & $0.04(0.03)$ & $0.05(0.03)$ \\
\hline Tenure & & $-0.11(0.09)$ & $-0.12(0.10)$ & $-0.11(0.10)$ & $-0.11(0.10)$ & $-0.11(0.10)$ & $-0.09(0.10)$ & $-0.11(0.10)$ & $-0.11(0.10)$ & $-0.10(0.10)$ & $-0.11(0.10)$ & $-0.10(0.09)$ \\
\hline $\begin{array}{l}\text { Employment } \\
\text { status }\end{array}$ & & $-0.18^{*}(0.10)$ & $-0.19 *(0.10)$ & $-0.18 *(0.10)$ & $-0.18^{*}(0.10)$ & $-0.18 *(0.10)$ & $-0.19 *(0.10)$ & $-0.18 *(0.10)$ & $-0.18^{*}(0.10)$ & $-0.20 *(0.10)$ & $-0.18^{*}(0.10)$ & $-0.19 *(0.10)$ \\
\hline $\begin{array}{l}\text { Trade Union } \\
\text { Member }\end{array}$ & & $-0.03(0.02)$ & $-0.04(0.03)$ & $-0.04(0.02)$ & $-0.04(0.02)$ & $-0.04(0.02)$ & $-0.05(0.01)$ & $-0.04(0.02)$ & $-0.04(0.02)$ & $-0.05(0.02)$ & $-0.04(0.02)$ & $-0.05(0.01)$ \\
\hline $\begin{array}{l}\text { Organisational } \\
\text { level (Level 2): } \\
\text { Control } \\
\text { Variables } \\
\end{array}$ & & & & & & & & & & & & \\
\hline $\begin{array}{l}\text { ln(Organisation } \\
\text { al } \\
\text { Size) }\end{array}$ & & & $0.18 * *(0.08)$ & $0.19 * *(0.08)$ & $0.19 * *(0.08)$ & $0.19 * *(0.08)$ & $0.18 * *(0.08)$ & $0.19 * *(0.08)$ & $0.18^{* *}(0.07)$ & $0.19 * *(0.08)$ & $0.19 * *(0.08)$ & $0.18^{* *}(0.07)$ \\
\hline Private Sector & & & $-0.11 *(0.06)$ & $-0.12 *(0.06)$ & $-0.12 *(0.06)$ & $-0.12 *(0.06)$ & $-0.11 *(0.06)$ & $-0.12 *(0.06)$ & $-0.12 *(0.06)$ & $-0.12 *(0.06)$ & $-0.13^{*}(0.07)$ & $-0.13^{*}(0.06)$ \\
\hline $\begin{array}{l}\text { Number } \\
\text { HPWPs }\end{array}$ & & & $-0.15 * *(0.06)$ & $-0.14^{* *}(0.06)$ & $-0.14^{* *}(0.06)$ & $-0.14 * *(0.06)$ & $-0.15^{* *}(0.06)$ & $-0.14 * *(0.06)$ & $-0.14^{* *}(0.06)$ & $-0.13^{* *}(0.06)$ & $-0.14^{* *}(0.06)$ & $-0.14^{* *}(0.05)$ \\
\hline NBPPs & & & $-0.09(0.06)$ & $-0.09(0.05)$ & $-0.09(0.05)$ & $-0.09(0.05)$ & $-0.10(0.06)$ & $-0.10(0.06)$ & $-0.09(0.05)$ & $-0.09(0.05)$ & $-0.10(0.06)$ & $-0.09(0.05)$ \\
\hline $\begin{array}{l}\text { Level } 2 \\
\text { Explanatory } \\
\text { Variables } \\
\end{array}$ & & & & & & & & & & & & \\
\hline $\begin{array}{l}\text { Targeted } \\
\text { Training } \\
\text { Incidence } \\
\text { (TT-I) }\end{array}$ & & & & & & & $-0.32 * * *(0.11)$ & & & & & \\
\hline $\begin{array}{l}\text { Targeted } \\
\text { Training } \\
\text { Hours (TT-H) }\end{array}$ & & & & & & & & $-0.22 *(0.12)$ & & & & \\
\hline $\begin{array}{l}\text { Targeted } \\
\text { Training }\end{array}$ & & & & & & & & & $-0.28^{* *}(0.12)$ & & & \\
\hline
\end{tabular}




\begin{tabular}{|c|c|c|c|c|c|c|c|c|c|c|c|c|}
\hline $\begin{array}{l}\text { Resources } \\
\text { (TTR) }\end{array}$ & & & & & & & & & & & & \\
\hline $\begin{array}{l}\text { Level } 1 \\
\text { Explanatory } \\
\text { Variables }\end{array}$ & & & & & & & & & & & & \\
\hline $\begin{array}{l}\text { Bullied past } 6 \\
\text { months }\end{array}$ & & & & $0.29^{* * *}(0.09)$ & & $0.18^{* *}(0.08)$ & $0.17 *(0.09)$ & $0.17 *(0.09)$ & $0.18 *(0.09)$ & $0.17 *(0.09)$ & $0.18 *(0.09)$ & $0.17 *(0.08)$ \\
\hline $\begin{array}{l}\text { Perceived } \\
\text { Effectiveness of } \\
\text { Implementation } \\
\text { (BPPs) }\end{array}$ & & & & & $--0.22 * *(0.09)$ & $-0.16^{* *}(0.08)$ & $-0.18^{* *}(0.08)$ & $-0.17 * *(0.08)$ & $-0.17^{* *}(0.07)$ & $-0.18^{* *}(0.08)$ & $-0.17 * *(0.08)$ & $-0.18^{* *}(0.08)$ \\
\hline $\begin{array}{l}\text { TT-H * } \\
\text { Perceived } \\
\text { Effective } \\
\text { Implementation }\end{array}$ & & & & & & & & & & & $-0.16 *(0.08)$ & \\
\hline $\begin{array}{l}\text { TT-R * } \\
\text { Perceived } \\
\text { Effective } \\
\text { Implementation }\end{array}$ & & & & & & & & & & & & $-0.21^{* *}(0.09)$ \\
\hline Pseudo- $R^{2}$ & & 0.08 & 0.20 & 0.31 & 0.32 & 0.34 & 0.36 & 0.34 & 0.35 & 0.41 & 0.37 & 0.40 \\
\hline $\begin{array}{l}\text { Variance } \\
\text { Components } \\
\text { Individual } \\
\text { level (Level-1) } \\
\text { Organisational } \\
\text { level (Level-2) } \\
\end{array}$ & $\begin{array}{l}0.253(0.022) \\
0.265(0.030)\end{array}$ & $\begin{array}{l}0.249(0.021) \\
0.260(0.028)\end{array}$ & $\begin{array}{l}0.247(0.020) \\
0.257(0.027)\end{array}$ & $\begin{array}{l}0.247(0.020) \\
0.257(0.027)\end{array}$ & $\begin{array}{l}0.247(0.020) \\
0.257(0.027)\end{array}$ & $\begin{array}{l}0.247(0.020) \\
0.257(0.027)\end{array}$ & $\begin{array}{l}0.247(0.020) \\
0.257(0.027)\end{array}$ & $\begin{array}{l}0.247(0.020) \\
0.257(0.027)\end{array}$ & $\begin{array}{l}0.247(0.020) \\
0.257(0.027)\end{array}$ & $\begin{array}{l}0.247(0.020) \\
0.257(0.027)\end{array}$ & $\begin{array}{l}0.247(0.020) \\
0.257(0.027)\end{array}$ & $\begin{array}{l}0.247(0.020) \\
0.257(0.027)\end{array}$ \\
\hline $\begin{array}{l}\text { Model } \\
\text { Deviance }\end{array}$ & 3376.28 & 2976.13 & 2765.22 & 2328.19 & 2198.71 & 2016.45 & 1987.12 & 1990.13 & 1988.28 & 1929.06 & 1931.41 & 1930.03 \\
\hline
\end{tabular}

Notes. see Table 3. 


\section{Endnotes}

i Paper copies of the survey were offered as an option for potential rural respondees who would often have poor internet connections, for those who may have wished to complete the survey during a break at work where internet access would not always be available and for potential respondees who were concerned that the on-line survey could be traced to an individual respondent. In total 12 paper surveys were returned. No biases between the on-line and paper respondents and their responses were found.

ii As the data on work place bullying reported in this paper are employees' self-report measures, it is recognised that what is analysed is 'perceived' work place bullying.

iii Despite the expected presence of anti-bullying policies in health care organisations in Ireland, a survey conducted in 2010 found that 38.5 percent of nurses reported that they had experienced workplace bullying (Mc Mahon, et al., 2013).

iv One possible explanation for only finding partial support for hypothesis 1 is that we were not able to control for the possibility that line managers may have engaged in bullying behaviours either in the past or even in the present. A line manager who bullies is likely to hinder effective implementation. Moreover, employees may perceive that training lacks value if his/her line manager engages/ed in bullying behaviours. We are grateful to an anonymous referee for this journal for highlighting this. 